\title{
Synthesis, Structure and Physicochemical Properties of a Saddle-Distorted Porphyrin with a Peripheral Carboxyl Group
}

\author{
Muniappan Sankar ${ }^{a}$, Tomoya Ishizuka ${ }^{a}$, Zeqing Wang ${ }^{b}$, Tingli Ma $^{b}$, Motoo Shiro ${ }^{c}$ and \\ Takahiko Kojima*a§
}

${ }^{a}$ Department of Chemistry, Graduate School of Pure and Applied Sciences, University of Tsukuba, Tennoudai 1-1-1, Tsukuba, Ibaraki 305-8571 Japan, 'btate Key Laboratory of Fine Chemicals, Dalian University of Technology, Gaoxinyuanqu, Dalian 116024, P. R. China, ${ }^{c}$ X-ray Research Laboratory, Rigaku Corporation, 3-9-12 Matsubara, Akishima, Tokyo 196-8666

Received date (to be automatically inserted after your manuscript is submitted) Accepted date (to be automatically inserted after your manuscript is accepted)

\begin{abstract}
A saddle-distorted porphyrin bearing a carboxyl group as a hydrogenbonding site on a meso-phenyl group was synthesized and characterized. A supramolecular structure with intermolecular hydrogen bonding was revealed by X-ray diffraction analysis. The effects of the peripheral carboxyl group on the physicochemical properties of the porphyrin as well as on self-assembly were investigated by spectroscopic measurements in solutions. The redox properties of the porphyrin and its $\mathrm{Zn}(\mathrm{II})$ complex were also studied by electrochemical measurements and their application to dye-sensitized solar cells was examined.
\end{abstract}

KEYWORDS: Dodecaphenylporphyrin, Hydrogen bonding, Supramolecules, Photovoltaics

\footnotetext{
*Correspondence to: Takahiko Kojima, Department of Chemistry, Graduate School of Pure and Applied Sciences, University of Tsukuba, Tennoudai 1-1-1, Tsukuba, Ibaraki 305-8571 Japan e-mail: kojima@chem.tsukuba.ac.jp. Tel and Fax: +81-29-853-4323. ${ }^{\S}$ An SPP full member in good standing
} 


\section{INTRODUCTION}

Supramolecular structures based on porphyrins and their derivatives have been intensively investigated for these decades due to the interest for the relevance to the natural photosynthetic center [1] as well as the applicability to functional materials such as photovoltaic cells [2]. In order to construct porphyrin supramolecules, various non-covalent interactions such as hydrogen bonding [3], $\pi-\pi$ interaction [4], halogen bonding [5] and van der Waals interaction [6] have been utilized so far. Among so many porphyrin derivatives, we have focused on non-planar porphyrins with saddletype conformational distortion and have reported various kinds of supramolecular structures by use of $2,3,5,7,8,10,12,13,15,17,18,20$-dodecaphenylporphyrin $\left(\mathrm{H}_{2} \mathrm{DPP}\right)$ [7]. For example, we have reported on the formation of porphyrin nanotube structures by use of $\mathrm{Mo}^{\mathrm{V}}$-DPP complexes, where polyoxomatalates (POMs) were included in the inner space of nano-sized tubular assemblies made of $\left[\mathrm{Mo}(\mathrm{DPP})(\mathrm{O})\left(\mathrm{H}_{2} \mathrm{O}\right)\right]^{+}$with hydrogen bonds between an axial aqua ligand at the central $\mathrm{Mo}^{\mathrm{V}}$ ion in the porphyrin core and the terminal oxo ligands of the POMs [8]. In the nanotube, the DPPs were integrated with intermolecular $\pi-\pi$ interactions among the peripheral phenyl groups. The diprotonated form of $\mathrm{H}_{2} \mathrm{DPP}\left(\mathrm{H}_{4} \mathrm{DPP}^{2+}\right)$ was also assembled by intermolecular $\pi-\pi$ interactions among the peripheral phenyl groups to afford nanochannel structures [9], which involve a relatively small inner space compared to those of the nanotubes based on Mo-DPP complexes. The inner space can be used for selective inclusion of electron-donating guest molecules such as TTF or hydroquinones in the single crystals. In the host-guest system, $\mathrm{H}_{4} \mathrm{DPP}^{2+}$ has been revealed to act as an electron acceptor [9a, 9b, 10] in the photoinduced electron transfer from included electrondonating guest molecules to exhibit photo-conducting properties [9a]. Furthermore, $\mathrm{H}_{4} \mathrm{DPP}^{2+}$ behaves as a hydrogen donor for hydrogen bond formation and takes two functional counter anions having carboxyl groups such as a $\mathrm{Zn}(\mathrm{II})$-phthalocyanine ( $\mathrm{ZnPc}$ ) complex with 4-pyridine carboxylate as an axial ligand [11] and ferrocene-carboxylate $(\mathrm{Fc})$ [12], which strongly interact with the $\mathrm{H}_{4} \mathrm{DPP}^{2+}$ core by hydrogen bonding. In the supramolecular triads, $\mathrm{H}_{4} \mathrm{DPP}^{2+}$ also functions as an electron acceptor and $\mathrm{ZnPc}$ or Fc as an electron donor to allow us to observe photoinduced electron transfer reactions to form charge-separated states.

In this study, we have introduced a carboxyl group as a hydrogen-bonding site at the periphery of $\mathrm{H}_{2} \mathrm{DPP}$ to develop supramolecular structures by virtue of the intermolecular hydrogen bonding. This hydrogen bonding is expected to be useful for emergence of novel structural motifs and to control the spacial arrangement of porphyrin supramolecular structures such as nanochannels in the crystal.

\section{EXPERIMENTAL}




\section{General}

All commercially available chemicals were purchased from appropriate sources and used as received unless otherwise mentioned. Methanolic solution of $(\mathrm{Me})_{4} \mathrm{NOH}(25 \mathrm{wt} \%$ solution, Aldrich) was received and appropriate concentrations were prepared in spectrocopic-grade methanol and used for UV-vis and ${ }^{1} \mathrm{H}$ NMR titrations. All NMR measurements were performed on a JEOL EX270 spectrometer. UV-vis absorption spectra were measured in spectroscopic-grade solvents on a Shimadzu UV-3600 spectrophotometer at r. t.. Fluorescence spectra were recorded on a Hamamatsu Photonics C9920-02 spectrometer at r. t.. Cyclic voltammograms were obtained at r. t. under Ar on an ALS 710D electrochemical analyser using a Pt wire as a counter electrode, a Pt working electrode, and $\mathrm{Ag} / \mathrm{AgNO}_{3}$ in $\mathrm{CH}_{3} \mathrm{CN}$ as a reference electrode. MALDI-TOF-MS spectra were measured on a Bruker UltrafleXtreme-TN MALDITOF/TOF spectrometer using dithranol as a matrix.

\section{Synthesis}

Preparation of Mono-Methyl Ester of TPP (5,10,15,20-Tetraphenylporphyrin) ( $\left.\mathrm{H}_{2} \mathrm{TPP}\left(\mathrm{CO}_{2} \mathrm{Me}\right)\right)$ [13]: Propionic acid (400 mL) was heated to $140{ }^{\circ} \mathrm{C}$ in a $1 \mathrm{~L}$ round-bottomed flask, and to this solvent, were added 4(methoxycarbonyl)benzaldehyde $(3.97 \mathrm{~g}, 0.0242 \mathrm{~mol})$, benzaldehyde $(7.6 \mathrm{~mL}, 0.074 \mathrm{~mol})$ and pyrrole $(6.7 \mathrm{~mL}, 0.097$ $\mathrm{mol}$ ) and the mixture was allowed to reflux for $90 \mathrm{~min}$. The solution was cooled to $\mathrm{r}$. $\mathrm{t}$. and the solvent was removed by evaporation under reduced pressure to give pink-gel residue. Hot water was added to the residue to remove excess propionic acid and pink powder was obtained. The obtained powder was dissolved in $\mathrm{CH}_{2} \mathrm{Cl}_{2}$ and filtered by a silica gel column eluted with $\mathrm{CH}_{2} \mathrm{Cl}_{2}$ and a crude product was obtained, which was slightly contaminated with corresponding chlorin derivatives. To the obtained fraction containing the precursor compound was added 2,3-dichloro-5,6-dicyano- $p$ benzoquinone (DDQ) $(1.85 \mathrm{~g}, 8.15 \mathrm{mmol})$ and the mixture was allowed to reflux for $8 \mathrm{~h}$ until no green spot was observed on a TLC plate. The reaction mixture was concentrated to the minimum volume and purified with column chromatography on a silica gel column eluted with $\mathrm{CH}_{2} \mathrm{Cl}_{2}$, and the target compound was obtained as the second fraction. The solvent of the fraction was evaporated and the residual solid was recrystallized from $\mathrm{CHCl}_{3} / \mathrm{CH}_{3} \mathrm{OH}$. Yield: $1.623 \mathrm{~g}(2.41 \mathrm{mmol}, 10 \%) .{ }^{1} \mathrm{H} \mathrm{NMR}\left(270 \mathrm{MHz} ; \mathrm{CDCl}_{3} ; \mathrm{Me}_{4} \mathrm{Si}\right): \delta_{\mathrm{u}}, \mathrm{ppm} 8.80$ (d, 6H, $J=5 \mathrm{~Hz}, \beta$-pyrrole- $H$ ), $8.73(\mathrm{~d}, 2 \mathrm{H}, J=6 \mathrm{~Hz}, \beta$-pyrrole- $H), 8.52$ and $8.28\left(\mathrm{ABq}, J_{\mathrm{AB}}=8 \mathrm{~Hz}, 4 \mathrm{H}, o\right.$ - and $m-\mathrm{H}$ of ester- $\left.\mathrm{Ph}\right), 8.22(\mathrm{dd}, 6 \mathrm{H}, J=7.0$, $2 \mathrm{~Hz}, o-H$ of $m e s o-\mathrm{Ph}), 7.82-7.71(\mathrm{~m}, 9 \mathrm{H}, m$ and $p-H$ of $m e s o-\mathrm{Ph}), 4.09$ (s, $\left.3 \mathrm{H},-\mathrm{COOCH}_{3}\right),-2.80(\mathrm{~s}, 2 \mathrm{H}, \mathrm{NH})$. UV-vis $\left(\mathrm{CH}_{2} \mathrm{Cl}_{2}\right): \lambda_{\max }, \mathrm{nm}(\log \varepsilon) 418$ (5.70), 515 (4.33), 550 (3.97), 590 (3.82), 647 (3.77). MS (MALDI-TOF): $m / z 673.63$ (Calcd. for $\mathrm{C}_{46} \mathrm{H}_{33} \mathrm{~N}_{4} \mathrm{O}_{2}[\mathrm{M}+\mathrm{H}]^{+}$: 673.79).

Preparation of CuTPP(CO $\boldsymbol{C O}_{2}$ Me $)$ [14]: $\mathrm{H}_{2} \mathrm{TPP}\left(\mathrm{CO}_{2} \mathrm{Me}\right)(1.25 \mathrm{~g}, 1.85 \mathrm{mmol})$ was dissolved in $\mathrm{CHCl}_{3}(200 \mathrm{~mL})$ and to the solution was added the suspension of $\mathrm{Cu}(\mathrm{OAc})_{2} \cdot \mathrm{H}_{2} \mathrm{O}(3.712 \mathrm{~g}, 18.6 \mathrm{mmol})$ in $\mathrm{CH}_{3} \mathrm{OH}(50 \mathrm{~mL})$. The reaction mixture was refluxed for $2 \mathrm{~h}$, evaporated to dryness, and the residue was dissolved in $\mathrm{CHCl}_{3}(150 \mathrm{~mL})$. The $\mathrm{CHCl}_{3}$ solution was washed with water, dried over $\mathrm{Na}_{2} \mathrm{SO}_{4}$, and concentrated to the minimum volume. The solution was loaded on a silica gel column, which was eluted with $\mathrm{CH}_{2} \mathrm{Cl}_{2}$. The obtained crude product was recrystallized from $\mathrm{CH}_{2} \mathrm{Cl}_{2} / \mathrm{CH}_{3} \mathrm{OH}$. Yield: $1.275 \mathrm{~g}(1.738 \mathrm{mmol}, 94 \%)$. UV-vis $\left(\mathrm{CH}_{2} \mathrm{Cl}_{2}\right): \lambda_{\max }, \mathrm{nm}(\log \varepsilon) 415$ (5.73), 466 (5.11), 538 (4.34), 570 (sh). MS (MALDI-TOF): $m / z 735.59$ (Calcd. for $\mathrm{C}_{46} \mathrm{H}_{31} \mathrm{~N}_{4} \mathrm{O}_{2} \mathrm{Cu}[\mathrm{M}+\mathrm{H}]^{+}:$735.32).

Preparation of CuTPP( CO $\left._{2} \mathbf{M e}\right)-\boldsymbol{B r}_{8}[14,15]$ : $\mathrm{CuTPP}\left(\mathrm{CO}_{2} \mathrm{Me}\right)(1.267 \mathrm{~g}, 1.72 \mathrm{mmol})$ was dissolved in $\mathrm{CHCl}_{3}(200 \mathrm{~mL})$ and the solution of $\mathrm{Br}_{2}(2.8 \mathrm{~mL}, 55 \mathrm{mmol})$ in $\mathrm{CHCl}_{3}(100 \mathrm{~mL})$ was added dropwise for 30 min and the mixture was allowed to stir for $4 \mathrm{~h}$ at $\mathrm{r}$. t.. A solution of pyridine $(6 \mathrm{~mL})$ in $\mathrm{CHCl}_{3}(100 \mathrm{~mL})$ was added very slowly and the reaction 
mixture was stirred overnight at r. t.. Then, excess bromine was quenched with aqueous solution of $\mathrm{Na}_{2} \mathrm{~S}_{2} \mathrm{O}_{5}(20 \%, 200$ $\mathrm{mL})$, washed with water $(200 \mathrm{~mL} \times 2)$, and concentrated to the minimum volume. The solution was loaded on a silica gel column, which was eluted with $\mathrm{CH}_{2} \mathrm{Cl}_{2}$. The crude product obtained was recrystallized from $\mathrm{CHCl}_{3} / \mathrm{MeOH} \mathrm{Yield}$ : $1.5 \mathrm{~g}$ of green powder (1.1 mmol, 64\%). UV-vis $\left(\mathrm{CH}_{2} \mathrm{Cl}_{2}\right): \lambda_{\max }, \mathrm{nm}(\log \varepsilon) 365$ (4.40), 453 (sh), 466 (5.11), 582 (4.21), 623 (3.78). MS (MALDI-TOF): $m / z$ 1365.22 (Calcd. for $\mathrm{C}_{46} \mathrm{H}_{22} \mathrm{~N}_{4} \mathrm{O}_{2} \mathrm{Br}_{8} \mathrm{Cu}[\mathrm{M}]^{+}$: 1365.47). Anal. Calcd. for $\mathrm{C}_{46} \mathrm{H}_{22} \mathrm{Br}_{8} \mathrm{~N}_{4} \mathrm{O}_{2} \mathrm{Cu} \cdot \mathrm{H}_{2} \mathrm{O}: \mathrm{C} ; 39.93, \mathrm{H} ; 1.75, \mathrm{~N} ; 4.05$, Found: $\mathrm{C} ; 39.70, \mathrm{H} ; 1.61, \mathrm{~N} ; 3.81$.

Preparation of $\mathbf{H}_{2} \boldsymbol{T P P}\left(\boldsymbol{C O}_{2} \mathbf{M e}\right)-\boldsymbol{B r}_{8}$ [14,15]: $\mathrm{CuTPP}\left(\mathrm{CO}_{2} \mathrm{Me}\right)-\mathrm{Br}_{8}(1.5 \mathrm{~g}, 1.1 \mathrm{mmol})$ was dissolved in $\mathrm{CHCl} \mathrm{H}_{3}(100 \mathrm{~mL})$, and the solution was cooled to $0{ }^{\circ} \mathrm{C}$. To the cooled solution, was slowly added conc. $\mathrm{H}_{2} \mathrm{SO}_{4}(10 \mathrm{~mL})$ at $0{ }^{\circ} \mathrm{C}$ and the reaction mixture was stirred for 20 min until the $\mathrm{CHCl}_{3}$ layer became colorless. It was transferred to a separating funnel, washed with water $(200 \mathrm{~mL} \times 2)$ and then neutralized with $\mathrm{NH}_{3}$ aq $(18 \%, 200 \mathrm{~mL})$. The organic layer was washed with water $(150 \mathrm{~mL})$, dried over $\mathrm{Na}_{2} \mathrm{SO}_{4}$ and then the solvent was evaporated. The residual solid was purified with column chromatography on silica gel using $\mathrm{CHCl}_{3}$ as an eluent. The obtained fraction was evaporated to dryness and dried under vacuum. Yield: $1.42 \mathrm{~g}(1.09 \mathrm{mmol}, 99 \%)$. ${ }^{1} \mathrm{H}$ NMR $\left(270 \mathrm{MHz} ; \mathrm{CDCl}_{3}\right)$ : $\delta_{\mathrm{H}}, \mathrm{ppm} 8.50$ and $8.25\left(\mathrm{ABq}, J_{\mathrm{AB}}=8 \mathrm{~Hz}\right.$, $4 \mathrm{H}, o$ - and $m-\mathrm{H}$ of ester- $\mathrm{Ph}), 8.17(\mathrm{~d}, 6 \mathrm{H}, J=6 \mathrm{~Hz}, o-H$ of $m e s o-\mathrm{Ph}), 7.84(\mathrm{~m}, 9 \mathrm{H}, m-$ and $p-H$ of $m e s o-\mathrm{Ph}), 4.1(\mathrm{~s}, 3 \mathrm{H},-$ $\left.\mathrm{COOCH}_{3}\right)$. UV-vis $\left(\mathrm{CH}_{2} \mathrm{Cl}_{2}\right): \lambda_{\max }$, nm (log $\left.\varepsilon\right) 370$ (4.40), 470 (5.27), 570 (3.93), 628 (4.12), 740 (3.85). MS (MALDITOF): $m / z 1305.28$ (Calcd. for $\mathrm{C}_{46} \mathrm{H}_{25} \mathrm{~N}_{4} \mathrm{O}_{2} \mathrm{Br}_{8}[\mathrm{M}+\mathrm{H}]^{+}:$1304.96). Anal. Calcd. for $\mathrm{C}_{46} \mathrm{H}_{24} \mathrm{~N}_{4} \mathrm{Br}_{8} \mathrm{O}_{2} \cdot \mathrm{CHCl}_{3}: \mathrm{C} ; 39.66, \mathrm{H}$; $1.77, \mathrm{~N} ; 3.94$, Found: C; 40.08, H; $1.91, \mathrm{~N} ; 3.92$.

Preparation of $\boldsymbol{H}_{2}$ DPP(CO $\boldsymbol{C}_{2}$ Me $): \mathrm{H}_{2} \mathrm{TPP}\left(\mathrm{CO}_{2} \mathrm{Me}\right)-\mathrm{Br}_{8}(0.35 \mathrm{~g}, 0.27 \mathrm{mmol}), \mathrm{PhB}(\mathrm{OH})_{2}(0.785 \mathrm{~g}, 6.44 \mathrm{mmol}), \mathrm{Pd}(\mathrm{PPh})_{4}$ (59 mg, $54 \mu \mathrm{mol})$ and $\mathrm{K}_{2} \mathrm{CO}_{3}(1.669 \mathrm{~g}, 12.1 \mathrm{mmol})$ were loaded in a $200 \mathrm{~mL}$ three-necked flask. This mixture was dried under vacuum for $30 \mathrm{~min}$ and then the inside of the flask was filled with Ar. Toluene (100 mL) was added and the mixture was heated to $90-100{ }^{\circ} \mathrm{C}$ under Ar atmosphere and stirred for $36 \mathrm{~h}$. After cooling to r. t., the volatile was removed by evaporation. The residue was dissolved in $\mathrm{CHCl}_{3}(100 \mathrm{~mL})$ and then washed with water $(100 \mathrm{~mL}), 12.5 \%$ $\mathrm{NH}_{3}$ aq $(100 \mathrm{~mL})$ and again with water $(150 \mathrm{~mL})$ and finally brine $(150 \mathrm{~mL})$. The organic phase was dried over $\mathrm{Na}_{2} \mathrm{SO}_{4}$ and purified on a silica gel column eluted with 3-8\% EtOAc in $\mathrm{CHCl}_{3}$. Yield: $0.254 \mathrm{~g}$ of green powder $(0.198 \mathrm{mmol}$, 74\%). ${ }^{1} \mathrm{H} \mathrm{NMR}\left(270 \mathrm{MHz} ; \mathrm{CDCl}_{3}\right): \delta_{\mathrm{H}}, \mathrm{ppm} 7.57(\mathrm{~d}, J=5 \mathrm{~Hz}, 6 \mathrm{H}, o-H$ of $m e s o-\mathrm{Ph}), 7.59$ and $7.36\left(\mathrm{ABq}, J_{\mathrm{AB}}=8 \mathrm{~Hz}\right.$, $4 \mathrm{H}, o$ - and $m$-H of ester- $\mathrm{Ph}), 6.50-6.90$ (m, 49H, $\beta$-pyrrole- $\mathrm{Ph}$ and $m, p$ - $H$ of meso- $\mathrm{Ph}$ ), 3.95 (s, 3H, -COOCH $)$. UV-vis $\left(\mathrm{CH}_{2} \mathrm{Cl}_{2}\right.$ with one drop $\left.\mathrm{Et}_{3} \mathrm{~N}\right): \lambda_{\max }, \mathrm{nm}(\log \varepsilon): 376$ (4.48), 469 (5.21), 566 (4.01), 618 (4.02), 725 (3.74). MS (MALDITOF): $m / z 1282.23$ (Calcd. for $\mathrm{C}_{94} \mathrm{H}_{65} \mathrm{~N}_{4} \mathrm{O}_{2}[\mathrm{M}+\mathrm{H}]^{+}:$1282.58).

Preparation of $\left[\mathrm{H}_{4} \boldsymbol{D P P}\left(\mathrm{CO}_{2} \mathrm{H}\right)\right]\left(\mathrm{ClO}_{4}\right)_{2}: \mathrm{H}_{2} \mathrm{DPP}\left(\mathrm{CO}_{2} \mathrm{Me}\right)(0.15 \mathrm{~g}, 0.12 \mathrm{mmol})$ was dissolved in a THF/EtOH mixed solvent $(3: 1 \mathrm{v} / \mathrm{v}, 40 \mathrm{~mL})$. To the solution was added the solution of $\mathrm{KOH}(1.6 \mathrm{~g}, 0.029 \mathrm{~mol})$ in water $(4 \mathrm{~mL})$ and refluxed under Ar overnight. After cooling to r. t., the solvent of the reaction mixture was removed under reduced pressure and acidified with $2 \mathrm{M} \mathrm{HCl}(40 \mathrm{~mL})$ yielded green precipitate. The precipitate was washed with water several times, filtered and dried under vacuum. The diprotonated porphyrin was neutralized by addition of $\mathrm{Et}_{3} \mathrm{~N}$ and the volatile was evaporated to obtain the crude product. The crude porphyrin was purified on a silica gel column eluted with $\mathrm{CHCl}_{3} / \mathrm{CH}_{3} \mathrm{OH}$ mixture $(9: 1 \mathrm{v} / \mathrm{v})$. After adding a few drops of $\mathrm{NEt}_{3}$, the solvent of the collected fraction was evaporated to give a crude product of $\left(\mathrm{HNEt}_{3}\right)\left[\mathrm{H}_{2} \mathrm{DPP}(\mathrm{COO})\right](0.125 \mathrm{~g})$. The resulting residual solid $(22 \mathrm{mg})$ of the crude porphyrin, $\left(\mathrm{HNEt}_{3}\right)\left[\mathrm{H}_{2} \mathrm{DPP}(\mathrm{COO})\right]$, was dissolved in THF $(5 \mathrm{~mL})$, and to the solution, $\mathrm{HClO}_{4}$ aq $(60 \%, 0.1 \mathrm{~mL})$ was added and stirred for a few minutes. The solvent was evaporated to dryness to yield green gel, and the resulting gel was dissolved in $\mathrm{CHCl}_{3}(15 \mathrm{~mL})$ and washed with water and dried under vacuum. The green residue was recrystallized from 
$\mathrm{CHCl}_{3} /$ ether (1:6, v/v). Yield: $23 \mathrm{mg}$ of green powder $(15.6 \mu \mathrm{mol}, 91 \%) .{ }^{1} \mathrm{H}$ NMR $\left(270 \mathrm{MHz} ; \mathrm{CDCl}_{3}\right): \delta_{\mathrm{u}}, \mathrm{ppm}^{8.05-}$ $7.84(\mathrm{~m}, 8 \mathrm{H}, o-H$ of carboxy- $\mathrm{Ph}$ and $o-H$ of meso-Ph), 7.78 (d, 2H, $J=8 \mathrm{~Hz}, m-H$ of carboxy-Ph), 7.40-7.00 (m, 9H, $m-$, p-H of meso-Ph), 7.00-6.40 (m, 40H, $\beta$-pyrrole- $\mathrm{Ph})$. UV-vis $\left(\mathrm{CH}_{2} \mathrm{Cl}_{2}\right): \lambda_{\max }, \mathrm{nm}(\log \varepsilon) 430(\mathrm{sh}), 487$ (5.38), 586 (3.62), 651 (4.06), 704 (4.69). FL $\left(\mathrm{CH}_{2} \mathrm{Cl}_{2}\right): \lambda_{\max }, \mathrm{nm}$ 759. MS (MALDI-TOF): $m / z$ 1269.49 (Calcd. for $\mathrm{C}_{93} \mathrm{H}_{64} \mathrm{~N}_{4} \mathrm{O}_{2}^{+}[\mathrm{M}]^{+}$: 1269.53). Anal. Calcd. for $\mathrm{C}_{93} \mathrm{H}_{64} \mathrm{~N}_{4} \mathrm{Cl}_{2} \mathrm{O}_{10} \cdot \mathrm{H}_{2} \mathrm{O}$ : C; 75.15, H; 4.48, N; 3.77, Found: C; 75.23, H; 4.57, N; 3.50 .

Preparation of $\mathbf{Z n D P P}\left(\boldsymbol{C O}_{2} \boldsymbol{H}\right)$ : The crude sample of $\left(\mathrm{HNEt}_{3}\right)\left[\mathrm{H}_{2} \mathrm{DPP}(\mathrm{COO})\right]$ (100 $\left.\mathrm{mg}\right)$ right after column chromatography was dissolved in $\mathrm{CHCl}_{3}(50 \mathrm{~mL})$ containing a few drops of $\mathrm{NEt}_{3}$. To the solution, was added $\mathrm{Zn}(\mathrm{OAc})_{2} \cdot 2 \mathrm{H}_{2} \mathrm{O}(130 \mathrm{mg}, 0.592 \mathrm{mmol})$ in $\mathrm{CH}_{3} \mathrm{OH}(5 \mathrm{~mL})$ and the mixture was heated to reflux for $2 \mathrm{~h}$. After cooling to r. t., the solution was evaporated to dryness. The green residual solid was dissolved in $\mathrm{CHCl}_{3}$ (40 $\mathrm{mL}$ ) to wash with water and the organic layer was dried over $\mathrm{Na}_{2} \mathrm{SO}_{4}$. The solvent was removed under reduced pressure and the residual solid was recrystallized from $\mathrm{CHCl}_{3} / \mathrm{Et}_{2} \mathrm{O}(1: 5 \mathrm{v} / \mathrm{v})$. Yield: $100 \mathrm{mg}$ of green powder $(0.075 \mathrm{mmol}, 95 \%)$. ${ }^{1} \mathrm{H} \mathrm{NMR}(270$ $\mathrm{MHz} ; \mathrm{CDCl}_{3}$ ): $\delta_{\text {н, }}$ ppm 8.05-7.25 (m, 8H, o-H of meso-Ph), 6.75-6.50 (m, 51H, $m-, p-H$ of meso-Ph and $\beta$-pyrrole- $H$ ). UV-vis $\left(\mathrm{CH}_{2} \mathrm{Cl}_{2}\right): \lambda_{\max }, \mathrm{nm}(\log \varepsilon) 375$ (4.37), 466 (5.17), 593 (4.01), 646 (3.82). FL $\left(\mathrm{CH}_{2} \mathrm{Cl}_{2}\right): \lambda_{\max }, \mathrm{nm}(\phi) 735(0.002)$. MS (MALDI-TOF): $m / z$ 1331.01 (Calcd. for $\mathrm{C}_{93} \mathrm{H}_{60} \mathrm{~N}_{4} \mathrm{O}_{2} \mathrm{Zn}[\mathrm{M}]^{+}:$1330.91). Anal. Calcd. for $\mathrm{C}_{93} \mathrm{H}_{60} \mathrm{~N}_{4} \mathrm{O}_{2} \mathrm{Zn} \cdot \mathrm{H}_{2} \mathrm{O}: \mathrm{C}_{\text {; }}$ 82.81, H; 4.63, N; 4.15, Found: C; 82.65, H; 4.48, N; 4.32 .

\section{X-ray Crystallography}

A dark-green single crystal of $\left[\mathrm{H}_{4} \mathrm{DPP}\left(\mathrm{CO}_{2} \mathrm{H}\right)\right](\mathrm{OH})_{2}$ (for a vacuum-dried sample: Anal. Calcd. for $\mathrm{C}_{93} \mathrm{H}_{64} \mathrm{~N}_{4} \mathrm{O}_{4} \cdot 5 \mathrm{H}_{2} \mathrm{O}: \mathrm{C} ; 80.27, \mathrm{H} ; 5.36, \mathrm{~N} ; 4.03$, Found: $\mathrm{C} ; 80.30, \mathrm{H} ; 5.43, \mathrm{~N} ; 3.84$ ) was obtained by recrystallization of the crude sample of $\left(\mathrm{HNEt}_{3}\right)\left[\mathrm{H}_{2} \mathrm{DPP}(\mathrm{COO})\right]$ from $\mathrm{CHCl}_{3} / \mathrm{MeOH}$ with vapor diffusion of $i$-PrOH. The diffraction data were measured on a Rigaku Mercury CCD system at Rigaku Corporation (Akishima, Tokyo, Japan). The data were integrated, scaled and corrected for absorption with the CrystalClear software [16]. Crystallographic data: $\mathrm{C}_{93} \mathrm{H}_{62} \mathrm{~N}_{4} \mathrm{O}_{2} \cdot 2 \mathrm{OH} \cdot 6 \mathrm{C}_{3} \mathrm{H}_{8} \mathrm{O}, F W=1662.10$, monoclinic, space group $P 2_{1} / c, a=30.628(2) \AA, b=30.1805(5) \AA, c=$ 40.738(3) $\AA, \beta=113.212(8)^{\circ}, V=34609(4) \AA^{3}, T=123 \mathrm{~K}, Z=16, D_{\mathrm{c}}=1.10 \mathrm{~g} \mathrm{~cm}^{-3}, \lambda(\mathrm{Cu} \mathrm{K} \alpha)=1.54187 \AA, 381208$ reflections measured, 62920 unique $\left(R_{\text {int }}=0.0471\right)$ which were used in all calculations. All calculations were performed using the Yadokari XG crystallographic software package [17]. The structure was solved by direct method (SHELXL97) [18] and refined by full-matrix least-squares methods on $F^{2}$ with 3146 parameters: $R 1=0.1296(I>2 \sigma(I))$ and $w R 2$ $=0.3552, \mathrm{GOF}=1.143, \mathrm{max} / \mathrm{min}$ residual density $1.870 /-0.397 \mathrm{e}^{-3}$. In the course of the structure refinements, we could not determine the positions of the solvent molecules of crystallization including water and 2-propanol molecules, which were clearly identified in difference Fourier maps, because of their severe disorder. Their contribution was thus subtracted from the diffraction pattern by the "Squeeze" program [19]. Crystallographic details are described in the cif file as Supporting Information.

\section{Device Fabrication}

Preparation of the working electrodes: The screen-printable $\mathrm{TiO}_{2}$ and $\mathrm{SnO}_{2}$ colloidal pastes and working electrodes were prepared according to the procedure developed by $\mathrm{Ma}$ and coworkers [20]. The working electrodes made of $\mathrm{TiO}_{2}$ and $\mathrm{SnO}_{2}$ were immersed into a $\mathrm{CH}_{2} \mathrm{Cl}_{2} / \mathrm{EtOH} \quad(9: 1$ v/v) solution of $\left(\mathrm{HNEt}_{3}\right)\left[\mathrm{H}_{2} \mathrm{DPP}(\mathrm{COO})\right]$ or $\mathrm{ZnDPP}\left(\mathrm{CO}_{2} \mathrm{H}\right)$ (with and without $0.2 \mathrm{mM}$ chenodeoxycholic acid (CDCA)) for $18 \mathrm{~h}$. The dye-sensitized $\mathrm{TiO}_{2}$ and $\mathrm{SnO}_{2}$ electrodes (thickness: $12-14 \mu \mathrm{m}$, area: $0.16 \mathrm{~cm}^{2}$ ) and a platinized counter electrode were assembled to fabricate solar cells by sandwiching a redox $\left(\mathrm{I}^{-} / \mathrm{I}_{3}{ }^{-}\right)$electrolyte solution. The 
electrolyte was composed of $0.03 \mathrm{M} \mathrm{I}_{2}, 0.06 \mathrm{M}$ LiI, 0.6 M 1-butyl-3-methylimidazolium iodide (BMII), $0.1 \mathrm{M}$ guanidinium thiocyanate, and 0.5 M 4-tert-butylpyridine (4TBP) in acetonitrile and 3-methoxypropionitrile.

Photovoltaic characterization: The current-voltage curves of the DSSCs were obtained by applying an external bias to the cell and by measuring the generated photocurrent under white light irradiation with a Keithley digital source meter (Keithley 2601, USA). The intensity of the incident light was $100 \mathrm{~mW} / \mathrm{cm}^{2}$, and the instrument was equipped with a $300 \mathrm{~W}$ solar simulator (Solar Light Co., INC., USA) that served as the light source. The photon flux was determined by a power meter (Nova, Ophir optronics Ltd.) and a calibration cell (BS-520, s/n 019, Bunkoh-Keiki Co., Ltd.).

\section{RESULTS AND DISCUSSION}

Synthesis: The target porphyrin was synthesized by the procedure described in Scheme 1, including abbreviations of synthetic intermediates and precursors together with schematic descriptions of their structures. The monoester-substituted TPP (5,10,15,20-tetraphenylporphyrin), $\mathrm{H}_{2} \mathrm{TPP}\left(\mathrm{CO}_{2} \mathrm{Me}\right)[13$, 14], was synthesized by Adler method with condensation of 4-(methoxycarbonyl)benzaldehyde and benzaldehyde with pyrrole in the ratio of 1:3:4 in propionic acid and purification by column chromatography gave the precursor in $10 \%$ yield. It was further metallated with $\mathrm{Cu}(\mathrm{OAc})_{2} \cdot \mathrm{H}_{2} \mathrm{O}$, followed by bromination using $\mathrm{Br}_{2} /$ pyridine in $60 \%$ yield for two steps $[14,15]$. Then, the central $\mathrm{Cu}$ ion in the porphyrin was removed by acid demetallation followed by neutralization with $\mathrm{NH}_{3}(\mathrm{aq})$ solution yielded freebase $\mathrm{H}_{2} \mathrm{TPP}\left(\mathrm{CO}_{2} \mathrm{Me}\right)-\mathrm{Br}_{8}$ in quantitative yield. Suzuki-Miyaura coupling reaction of $\mathrm{H}_{2} \mathrm{TPP}\left(\mathrm{CO}_{2} \mathrm{Me}\right)-\mathrm{Br}_{8}$ with phenylboronic acid afforded $\mathrm{H}_{2} \mathrm{DPP}\left(\mathrm{CO}_{2} \mathrm{Me}\right)$ in $74 \%$ yield. $\mathrm{H}_{2} \mathrm{DPP}\left(\mathrm{CO}_{2} \mathrm{Me}\right)$ was subjected to alkaline hydrolysis with $\mathrm{KOH}$ to afford $\mathrm{K}\left[\mathrm{H}_{2} \mathrm{DPP}(\mathrm{COO})\right]$. The potassium salt was neutralized with $\mathrm{HCl}$ aq and the obtained crude chloride salt of the diprotonated porphyrin, $\left[\mathrm{H}_{4} \mathrm{DPP}\left(\mathrm{CO}_{2} \mathrm{H}\right)\right] \mathrm{Cl}_{2}$, was neutralized again with excess triethylamine $\left(\mathrm{Et}_{3} \mathrm{~N}\right)$ and the

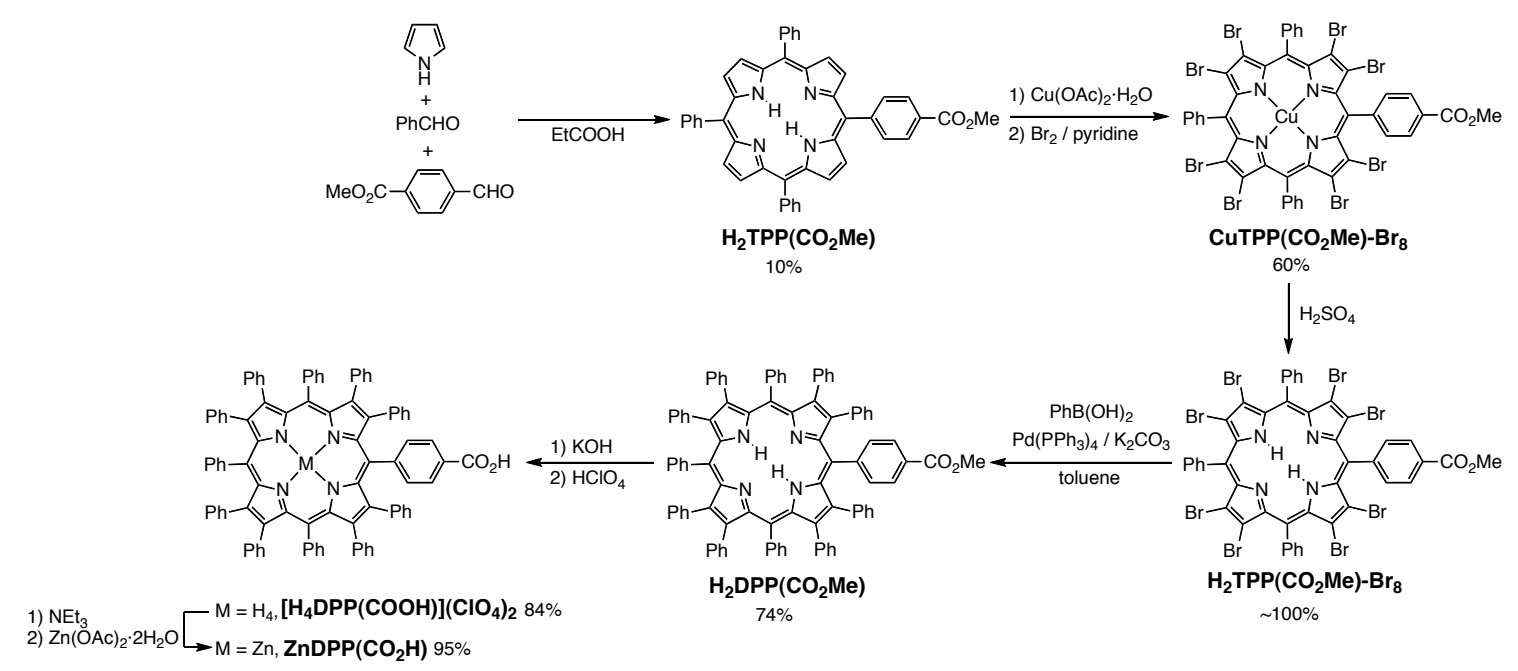

Scheme 1. Synthesis of $\left[\mathrm{H}_{4} \mathrm{DPP}\left(\mathrm{CO}_{2} \mathrm{H}\right)\right]\left(\mathrm{ClO}_{4}\right)_{2}$ and $\mathrm{ZnDPP}(\mathrm{COOH})$. 
crude product was purified with column chromatography. The perchloric acid salt of $\mathrm{H}_{2} \mathrm{DPP}(\mathrm{COOH})\left(\left[\mathrm{H}_{4} \mathrm{DPP}\left(\mathrm{CO}_{2} \mathrm{H}\right)\right]\left(\mathrm{ClO}_{4}\right)_{2}\right)$ as the diprotonated species at the porphyrin core was readily obtained by the treatment of crude $\left(\mathrm{HNEt}_{3}\right)\left[\mathrm{H}_{2} \mathrm{DPP}(\mathrm{COO})\right]$, which was obtained from the column chromatography, in $\mathrm{CH}_{2} \mathrm{Cl}_{2}$ with aqueous $\mathrm{HClO}_{4}$. In addition, after the neutralization of the porphyrin core, it was metallated with $\mathrm{Zn}(\mathrm{OAc})_{2} \cdot 2 \mathrm{H}_{2} \mathrm{O}$ to give $\mathrm{ZnDPP}\left(\mathrm{CO}_{2} \mathrm{H}\right)$ in quantitative yield.

Crystal Structure of $\left[\mathbf{H}_{4} \mathbf{D P P}(\mathbf{C O O H})\right]^{2+}:\left(\mathrm{HNEt}_{3}\right)\left[\mathrm{H}_{2} \mathrm{DPP}(\mathrm{COO})\right]$ was recrystallized from a $\mathrm{CHCl}_{3} / \mathrm{MeOH} / 2$-propanol ( $i$-PrOH) mixed solvent with vapor diffusion method to afford dark-green single crystals and the crystal structure was determined by X-ray diffraction analysis (Fig. 1). The asymmetric unit contained four independent porphyrin molecules and each porphyrin core of the four molecules was found to be diprotonated probably by the solvent or water as a proton source during the recrystallization $[21,22]$. The $\left[\mathrm{H}_{4} \mathrm{DPP}\left(\mathrm{CO}_{2} \mathrm{H}\right)\right]^{2+}$ ion holds two $\mathrm{OH}^{-}$ions as the counter anions, which formed hydrogen bonds with the pyrrole $\mathrm{NH}$ of the diprotonated porphyrin core. The mean $\mathrm{O} \cdots \mathrm{N}$ distance of the 16 hydrogen bonds was $3.19 \AA$ in the asymmetric unit containing four $\left[\mathrm{H}_{4} \mathrm{DPP}\left(\mathrm{CO}_{2} \mathrm{H}\right)\right](\mathrm{OH})_{2}$. The $\mathrm{OH}^{-}$ion also forms hydrogen bonding with $i-\mathrm{PrOH}$, as shown in Fig.

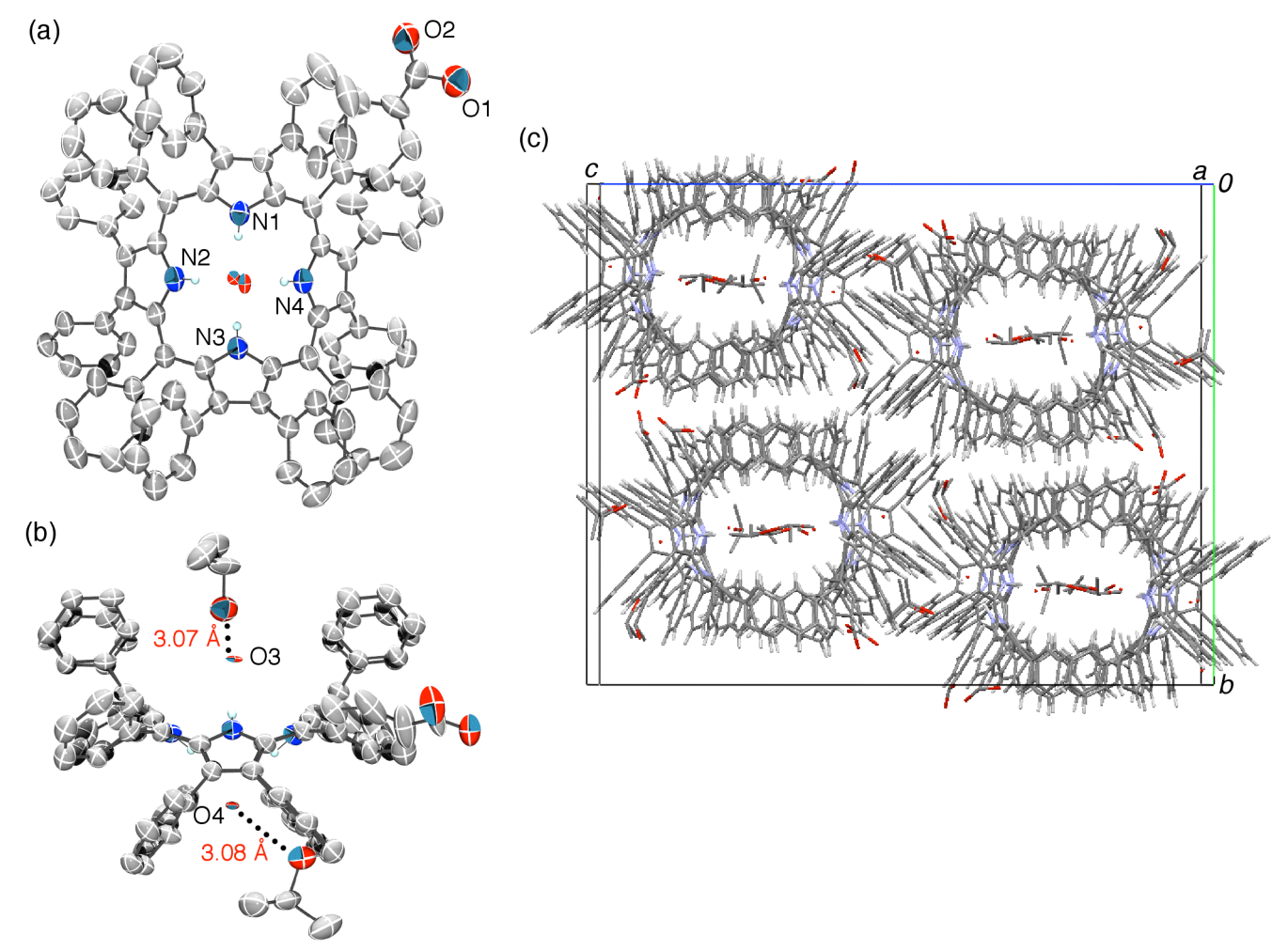

Fig. 1. Crystal Structure of $\left[\mathrm{H}_{4} \mathrm{DPP}\left(\mathrm{CO}_{2} \mathrm{H}\right)\right](\mathrm{OH})_{2}$ : (a) a top view; (b) a side view including hydrogen bonds between $\mathrm{OH}^{-}$ions and co-crystallized $i$-PrOH molecules; (c) a view of the crystal packing along the crystallographic $a$ axis including solvent molecules ( $i-\mathrm{PrOH}$ and $\mathrm{H}_{2} \mathrm{O}$ ) of crystallization. 
1(b), and this hydrogen bonding may weaken the basicity of the $\mathrm{OH}^{-}$ion to stabilize it without accepting proton from $\left[\mathrm{H}_{4} \mathrm{DPP}\left(\mathrm{CO}_{2} \mathrm{H}\right)\right]^{2+}$. In the crystal packing, the $\left[\mathrm{H}_{4} \mathrm{DPP}\left(\mathrm{CO}_{2} \mathrm{H}\right)\right]^{2+}$ ions formed a nanochannel structure similarly to the case of $\mathrm{H}_{4} \mathrm{DPP}^{2+}[9]$ and the inner space of the nanochannel was occupied with co-crystallized solvent molecules such as $i$-PrOH and water. The pore size of the nanochannel was $0.97 \times 0.75 \mathrm{~nm}$, which was almost the same as that of $\mathrm{H}_{4} \mathrm{DPP}^{2+}$ nanochannnel $(1.0$ $\times 0.7 \mathrm{~nm})[9]$. The noteworthy difference between the nanochannel of $\left[\mathrm{H}_{4} \mathrm{DPP}\left(\mathrm{CO}_{2} \mathrm{H}\right)\right]^{2+}$ and that of $\mathrm{H}_{4} \mathrm{DPP}^{2+}$ is relative spatial arrangement of the channels: In the case of $\mathrm{H}_{4} \mathrm{DPP}^{2+}$, nanochannels were closely packed by $\pi-\pi$ stacking among the adjacent channels. On the other hand, nanochannels formed by $\left[\mathrm{H}_{4} \mathrm{DPP}\left(\mathrm{CO}_{2} \mathrm{H}\right)\right]^{2+}$ were relatively separated due to the formation of intermolecular hydrogen bonding between the carboxyl groups at the peripheries of the porphyrins, which belonged to neighboring channels.

There were four independent carboxyl groups found in the crystal and they formed hydrogen-bonding pairs as shown in Fig. 2. Two of them formed a complementary hydrogenbonding pair as shown in Fig. 2(a). One of $\left[\mathrm{H}_{4} \mathrm{DPP}\left(\mathrm{CO}_{2} \mathrm{H}\right)\right]^{2+}$ ions, which is depicted on the lefthand side in Fig. 2(b), exhibited positional disorder of the carboxyl group into pseudo-orthogonal directions with 0.5 population for each. The half of them formed the complementary hydrogen bonding. The other half exhibited a partial hydrogen bonding, where one of the two oxygen atoms

(a)

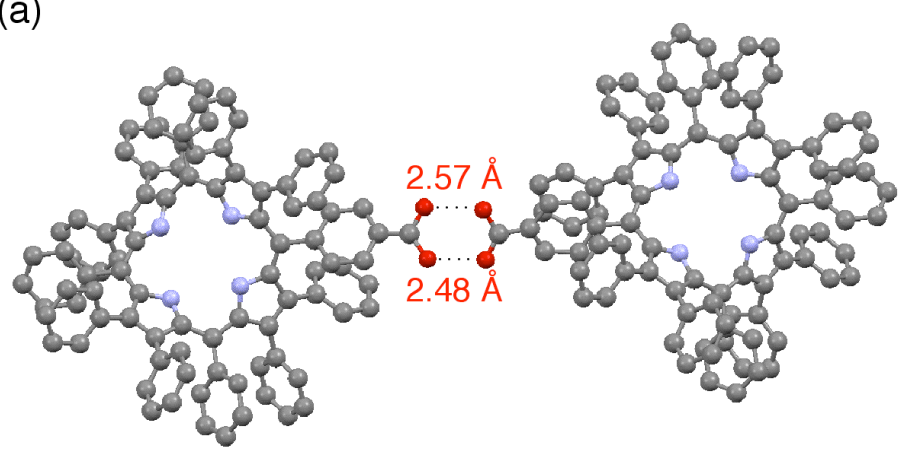

(b)

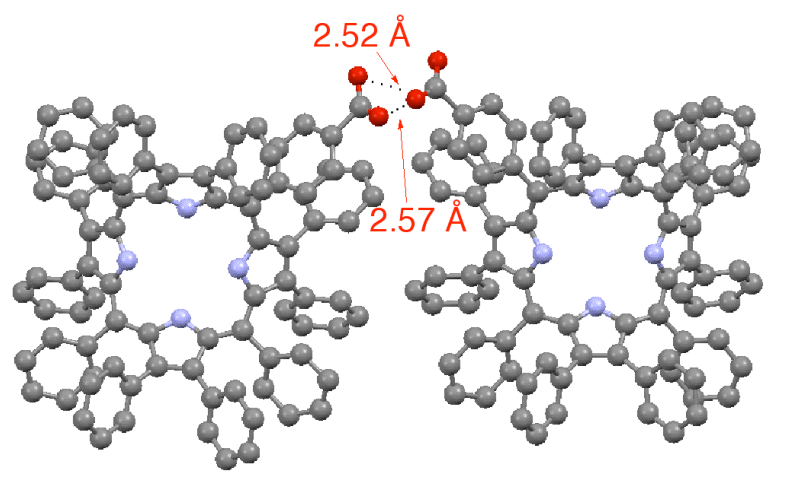

Fig. 2. Hydrogen bonding for the carboxyl group: (a) A complementary hydrogen bonding pair; (b) another hydrogen bonding pattern for the carboxyl groups. 
of the carboxyl group formed hydrogen bonding with two of the other carboxyl group and the remaining oxygen atom, which did not participate in the hydrogen bonding, interacted with severely disordered $i$-PrOH molecules of crystallization (see Fig. 2(b)) [23]. As a result of this interchannel hydrogen bonding, the distances between nanochannels increased (interchannel distances of $\mathrm{H}_{4} \mathrm{MCDPP}^{2+}, 15.3 \times 15.3 \times 20.5 \AA$; those of $\mathrm{H}_{4} \mathrm{DPP}^{2+}, 15.1 \times 15.1 \times 19.5 \AA$ [9]) and the space between the channels was occupied with solvent molecules of crystallization.

Spectral and Electrochemical Properties: The absorption spectrum of $\left(\mathrm{HNEt}_{3}\right)\left[\mathrm{H}_{2} \mathrm{DPP}(\mathrm{COO})\right]$, which was obtained by treatment of $\left[\mathrm{H}_{4} \mathrm{DPP}\left(\mathrm{CO}_{2} \mathrm{H}\right)\right]\left(\mathrm{ClO}_{4}\right)_{2}\left(7.6 \times 10^{-6} \mathrm{M}\right)$ with excess amount of $\mathrm{NEt}_{3}$, exhibited the absorption maxima at 470 (Soret), 567, 620, and $727 \mathrm{~nm}$ (Q band) in $\mathrm{CH}_{2} \mathrm{Cl}_{2}$. That of $\mathrm{ZnDPP}\left(\mathrm{CO}_{2} \mathrm{H}\right)$ in $\mathrm{CH}_{2} \mathrm{Cl}_{2}$ exhibited the same features as that of $\mathrm{ZnDPP}$ (red line in Fig. 3a)

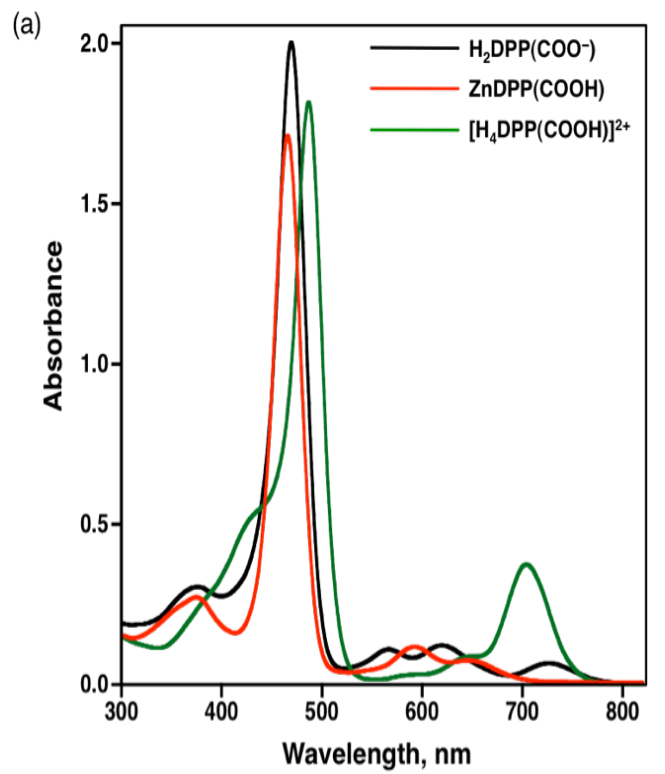

(b)

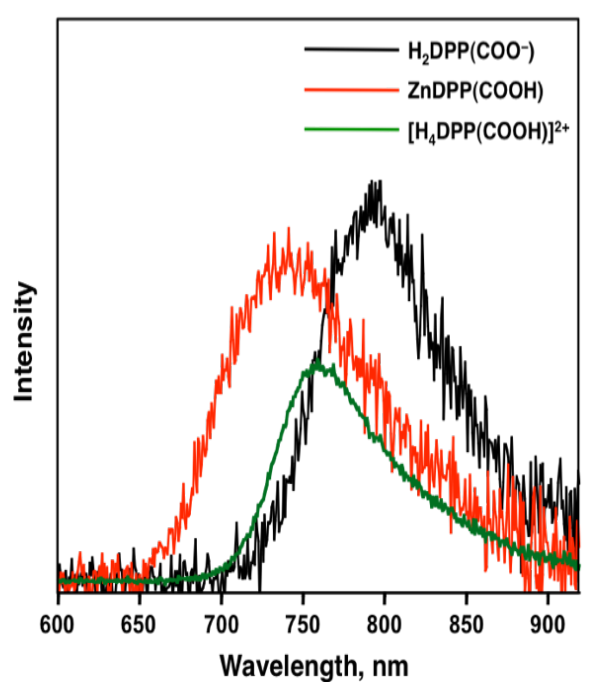

Fig. 3. UV-Vis (a) and fluorescence spectra (b) of $\left(\mathrm{HNEt}_{3}\right)\left[\mathrm{H}_{2} \mathrm{DPP}(\mathrm{COO})\right]$ (black), $\left[\mathrm{H}_{4} \mathrm{DPP}\left(\mathrm{CO}_{2} \mathrm{H}\right)\right]\left(\mathrm{ClO}_{4}\right)_{2}$ (green) and $\mathrm{ZnDPP}\left(\mathrm{CO}_{2} \mathrm{H}\right)$ (red) in $\mathrm{CH}_{2} \mathrm{Cl}_{2}$. 
and $\left[\mathrm{H}_{4} \mathrm{DPP}\left(\mathrm{CO}_{2} \mathrm{H}\right)\right]^{2+}$ shows a typical spectrum for a diprotonated porphyrin with a red-shifted Soret band (green line in Fig. 2a) compared to that of the corresponding neutral porphyrin core, which is reminiscent of that of $\mathrm{H}_{4} \mathrm{DPP}^{2+}[9 \mathrm{~b}, 10]$. The electronic effect on the UV-Vis absorption of the DPP core by the introduction of the carboxyl group was very small: The shifts of the Soret bands for $\left(\mathrm{HNEt}_{3}\right)\left[\mathrm{H}_{2} \mathrm{DPP}(\mathrm{COO})\right](470 \mathrm{~nm}),\left[\mathrm{H}_{4} \mathrm{DPP}\left(\mathrm{CO}_{2} \mathrm{H}\right)\right]\left(\mathrm{ClO}_{4}\right)_{2}(487 \mathrm{~nm})$ and $\mathrm{ZnDPP}\left(\mathrm{CO}_{2} \mathrm{H}\right)$ (466 nm) were $1 \sim 2 \mathrm{~nm}$ toward lower energy in each case in comparison with those of the corresponding DPP counterparts [24]. The fluorescence spectra of $\left(\mathrm{HNEt}_{3}\right)\left[\mathrm{H}_{2} \mathrm{DPP}(\mathrm{COO})\right]$, $\left[\mathrm{H}_{4} \mathrm{DPP}\left(\mathrm{CO}_{2} \mathrm{H}\right)\right]\left(\mathrm{ClO}_{4}\right)_{2}$, and $\mathrm{ZnDPP}\left(\mathrm{CO}_{2} \mathrm{H}\right)$ were measured in $\mathrm{CH}_{2} \mathrm{Cl}_{2}$ at $r$. $t$. to observe the emission maxima at 793, 759, and $735 \mathrm{~nm}$, respectively, as depicted in Fig. 3(b). These emission maxima are also marginally shifted relative to those of MDPP $\left(\mathrm{M}=\mathrm{H}_{2}, \mathrm{H}_{4}, \mathrm{Zn}\right)$ [25].

Redox potentials of $\left(\mathrm{HNEt}_{3}\right)\left[\mathrm{H}_{2} \mathrm{DPP}(\mathrm{COO})\right],\left[\mathrm{H}_{4} \mathrm{DPP}\left(\mathrm{CO}_{2} \mathrm{H}\right)\right]\left(\mathrm{ClO}_{4}\right)_{2}$ and $\mathrm{ZnDPP}\left(\mathrm{CO}_{2} \mathrm{H}\right)$ in $\mathrm{CH}_{2} \mathrm{Cl}_{2}$ are summarized in Table 1 together with the data of the corresponding DPP and TPP species. The redox waves due to the oxidation and reduction processes are reversible for the diprotonated species and $\mathrm{Zn}$ complexes, whereas those for $\left(\mathrm{HNEt}_{3}\right)\left[\mathrm{H}_{2} \mathrm{DPP}(\mathrm{COO})\right]$ and $\mathrm{H}_{2} \mathrm{DPP}$ are irreversible. The first oxidation and reduction potentials of $\left(\mathrm{HNEt}_{3}\right)\left[\mathrm{H}_{2} \mathrm{DPP}(\mathrm{COO})\right]$, $\left[\mathrm{H}_{4} \mathrm{DPP}\left(\mathrm{CO}_{2} \mathrm{H}\right)\right]\left(\mathrm{ClO}_{4}\right)_{2}$ and $\mathrm{ZnDPP}\left(\mathrm{CO}_{2} \mathrm{H}\right)$ were almost similar to those of the corresponding DPP counterpart despite of the introduction of a carboxyl group. Comparison of the redox potentials of $\mathrm{DPP}\left(\mathrm{CO}_{2} \mathrm{H}\right) \mathrm{s}$ to those of TPPs revealed a clear tendency of the narrower HOMO-LUMO gaps of highly distorted porphyrins relative to those of planar ones. In addition, the $\operatorname{DPP}\left(\mathrm{CO}_{2} \mathrm{H}\right) \mathrm{s}$ showed more negative LUMO levels than the conduction-band edge of $\mathrm{TiO}_{2}$, but the $\mathrm{HOMO}$ levels are only

Table 1. Redox Potentials $\left(E_{1 / 2}\right)$ of $\mathrm{DPP}\left(\mathrm{CO}_{2} \mathrm{H}\right)$ in $\mathrm{CH}_{2} \mathrm{Cl}_{2}{ }^{\text {a }}$

\begin{tabular}{|c|c|c|c|}
\hline \multirow{2}{*}{} & \multicolumn{2}{|c|}{ Oxidation (V) } & Reduction (V) \\
\cline { 2 - 4 } & I & II & I \\
\hline$\left(\mathrm{HNEt}_{3}\right)\left[\mathrm{H}_{2} \mathrm{DPP}(\mathrm{COO})\right]^{\mathrm{b}}$ & $+0.26^{\mathrm{c}}$ & - & $-1.55^{\mathrm{c}}$ \\
\hline$\left[\mathrm{H}_{4} \mathrm{DPP}\left(\mathrm{CO}_{2} \mathrm{H}\right)\right]\left(\mathrm{ClO}_{4}\right)_{2}$ & +1.18 & - & -0.55 \\
\hline $\mathrm{ZnDPP}\left(\mathrm{CO}_{2} \mathrm{H}\right)$ & +0.31 & +0.42 & $-1.61^{\mathrm{c}}$ \\
\hline $\mathrm{H}_{2} \mathrm{DPP}$ & $+0.32^{\mathrm{c}}$ & - & $-1.57^{\mathrm{c}}$ \\
\hline$\left[\mathrm{H}_{4} \mathrm{DPP}\right]\left(\mathrm{ClO}_{4}\right)_{2}$ & +1.11 & +1.40 & -0.59 \\
\hline $\mathrm{ZnDPP}$ & +0.29 & +0.40 & -1.65 \\
\hline $\mathrm{H}_{2} \mathrm{TPP}$ & +0.75 & +1.08 & $-1.50^{\mathrm{c}}$ \\
\hline $\mathrm{ZnTPP}$ & +0.60 & +0.91 & -1.61 \\
\hline
\end{tabular}

${ }^{\mathrm{a}}$ Supporting electrolyte: $\mathrm{TBAPF}_{6}(0.1 \mathrm{M})$, Potentials vs $\mathrm{Ag} / \mathrm{AgNO}_{3}$ in $\mathrm{CH}_{3} \mathrm{CN}$ as a reference electrode, a Pt working electrode, a Pt wire as a counter electrode.

${ }^{\mathrm{b}}$ In order to avoid the protonation at the porphyrin core, a few drops of triethylamine was added to the sample solution.

${ }^{\mathrm{c}}$ For irreversible redox processes, potentials of the DPV peaks were given. 
a little positive compared to the oxidation potential for the $\mathrm{I}^{-} / \mathrm{I}_{3}{ }^{-}$mediator. The latter situation may be disadvantage for the dye regeneration in a DSSC system (vide infra).

Spectral Changes with Acid-Base Titration: The saddle-distorted DPP tends to be easily diprotonated because the lone pairs of the pyrrolic nitrogens of DPP as the protonated sites direct out of the porphyrin plane by the distortion of the porphyrin skeleton and are easily accessible for protons. In addition, the diprotonated species of DPPs are stabilized by hydrogen bonding between counter anions, where the two counter anions are placed at the space above and below the porphyrin plane and form hydrogen bonds with trans-located two pyrrolic N-Hs of the saddle-distorted porphyrin, which are diagonally positioned each other, as can be seen in Fig. 1.

We examined the spectroscopic titration of $\left[\mathrm{H}_{4} \mathrm{DPP}\left(\mathrm{CO}_{2} \mathrm{H}\right)\right]\left(\mathrm{ClO}_{4}\right)_{2}$ in $\mathrm{CHCl}_{3}$ with $\left[\mathrm{Me}_{4} \mathrm{~N}\right] \mathrm{OH}$ at r. t. to elucidate the order of acidity of protons included. Upon the addition of the first

(a)

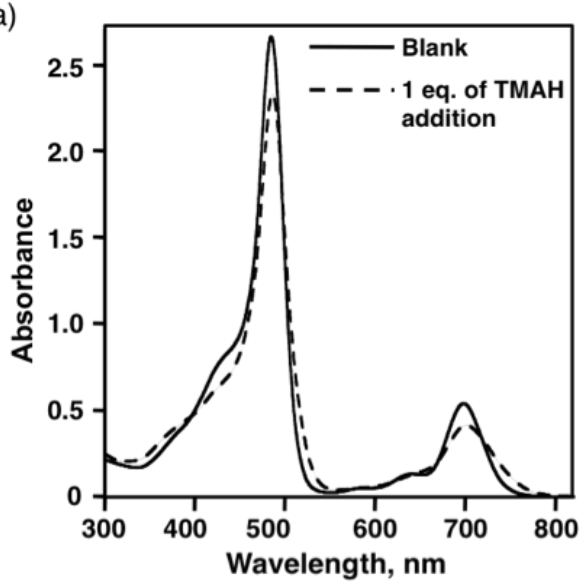

(c)

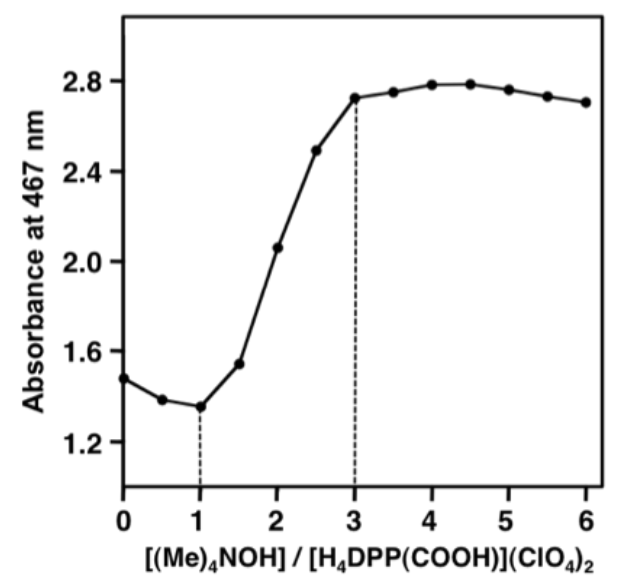

(b)

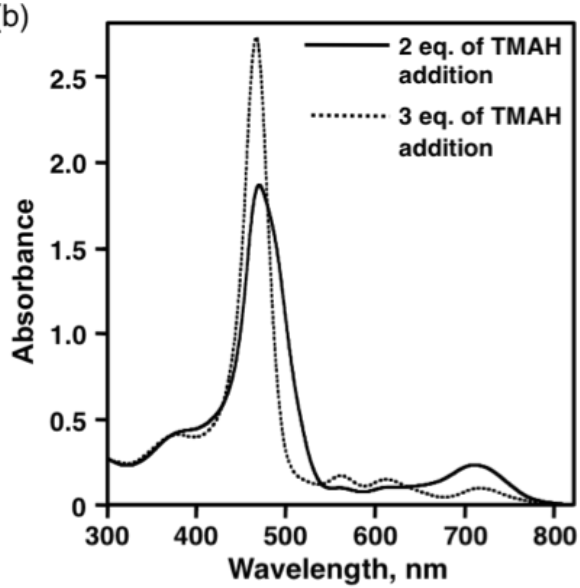

(d)

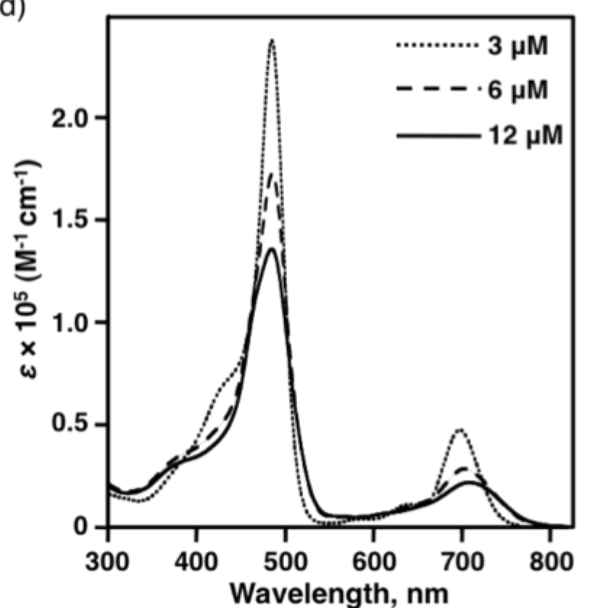

Fig. 4. Spectroscopic titration of $\left[\mathrm{H}_{4} \mathrm{DPP}\left(\mathrm{CO}_{2} \mathrm{H}\right)\right]\left(\mathrm{ClO}_{4}\right)_{2}\left(1.2 \times 10^{-5} \mathrm{M}\right)$ with $\left[\mathrm{Me}_{4} \mathrm{~N}\right] \mathrm{OH}$ in $\mathrm{CHCl}_{3}$ at r. t.: (a) Spectral change in the course of the addition of 1 eq of the base; (b) Spectral change for the addition of $2-3$ eq of the base; (c) Change of absorbance at $467 \mathrm{~nm}$ relative to the equivalency of the base; (d) Effect of concentration on the absorption spectra at different porphyrin concentrations $(3 \mu \mathrm{M}, 6 \mu \mathrm{M}, 12 \mu \mathrm{M})$ with corresponding 1 eq addition of $\left[\mathrm{Me}_{4} \mathrm{~N}\right] \mathrm{OH}$ in $\mathrm{CHCl}_{3}$. 
equivalent of $\mathrm{OH}^{-}$, the absorption spectrum of $\left[\mathrm{H}_{4} \mathrm{DPP}\left(\mathrm{CO}_{2} \mathrm{H}\right)\right]\left(\mathrm{ClO}_{4}\right)_{2}$ showed only small change without showing isosbestic points, as depicted in Fig. 4(a). In sharp contrast, the addition of the second and the third equivalents of the base allowed us to observe significant spectral change without isosbestic points, as shown in Fig. 4(b). Further addition of the base did not afford any spectral change. The absorbance change at $467 \mathrm{~nm}$ was monitored relative to the equivalency of $\mathrm{OH}^{-}$to the diprotonated porphyrin. The resultant titration curve is displayed in Fig. 4(c), indicating that the first step is mono-deprotonation followed by two successive deprotonation processes. Thus we concluded that the first deprotonation occurs at the carboxyl group and then the deprotonation of the protons attached to the pyrroles in a successive manner without formation of the corresponding mono-protonated form of the porphyrin core [26], as summarized in Scheme 2.

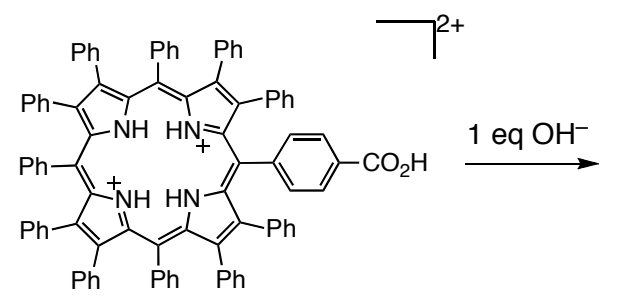

$\left[\mathrm{H}_{4} \mathrm{DPP}\left(\mathrm{CO}_{2} \mathrm{H}\right)\right]^{2+}$

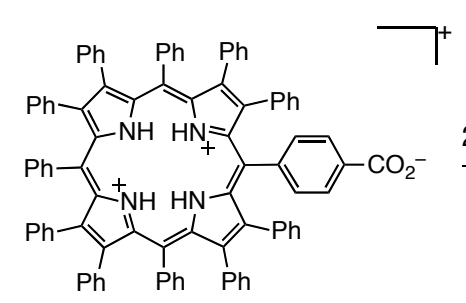

$\left[\mathrm{H}_{4} \mathrm{DPP}(\mathrm{COO})\right]^{+}$

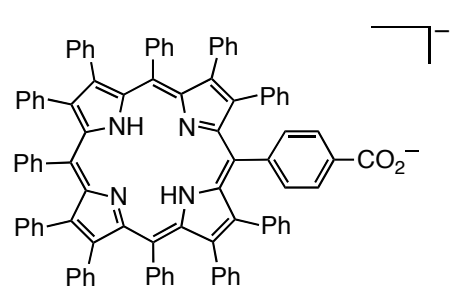

$\left[\mathrm{H}_{2} \mathrm{DPP}(\mathrm{COO})\right]^{-}$

Scheme 2. A Plausible Deprotonation Sequence of $\left[\mathrm{H}_{4} \mathrm{DPP}\left(\mathrm{CO}_{2} \mathrm{H}\right)\right]^{2+}$.

In the previous reports, we utilized the hydrogen bonding between diprotonated DPP and counter anions having a carboxylate group for formation of supramolecular structures $[11,12]$. The carboxylate-appended $\left[\mathrm{H}_{4} \mathrm{DPP}(\mathrm{COO})\right]^{+}$, which should be derived from the first deprotonation at the carboxyl group of $\mathrm{H}_{4} \mathrm{MCDPP}^{2+}$ (see Scheme 2), is expected to form self-assembled structures through intermolecular hydrogen bonding between the diprotonated porphyrin core and the peripheral carboxylate moiety. Thus, we examined the concentration dependence on the absorption spectra of the carboxylate-appended porphyrin dication, $\left[\mathrm{H}_{4} \mathrm{DPP}(\mathrm{COO})\right]^{+}$, in $\mathrm{CHCl}_{3}$ (Fig. 3(d)) to observe that the Soret band gradually lowered its molar absorption coefficient with increasing the concentration of the porphyrin. This kind of behaviors can be ascribed to the self-aggregation of chromophores as observed in that of water-soluble porphyrins [27]. In addition, the observation that the spectral change in the course of the deprotonation processes does not give isosbestic points (vide supra) also suggests the emergence of supramolecular structures in accordance with the formation of the $\left[\mathrm{H}_{4} \mathrm{DPP}(\mathrm{COO})\right]^{+}$species.

In order to shed some lights on the self-assembly of the carboxylate-appended porphyrin dication derived from the carboxylate-appended $\left[\mathrm{H}_{4} \mathrm{DPP}(\mathrm{COO})\right]^{+}$, we conducted titration experiments using ${ }^{1} \mathrm{H}$ NMR spectroscopy on the $2.0 \mathrm{mM}$ solution of $\left[\mathrm{H}_{4} \mathrm{DPP}\left(\mathrm{CO}_{2} \mathrm{H}\right)\right]\left(\mathrm{ClO}_{4}\right)_{2}$ in 


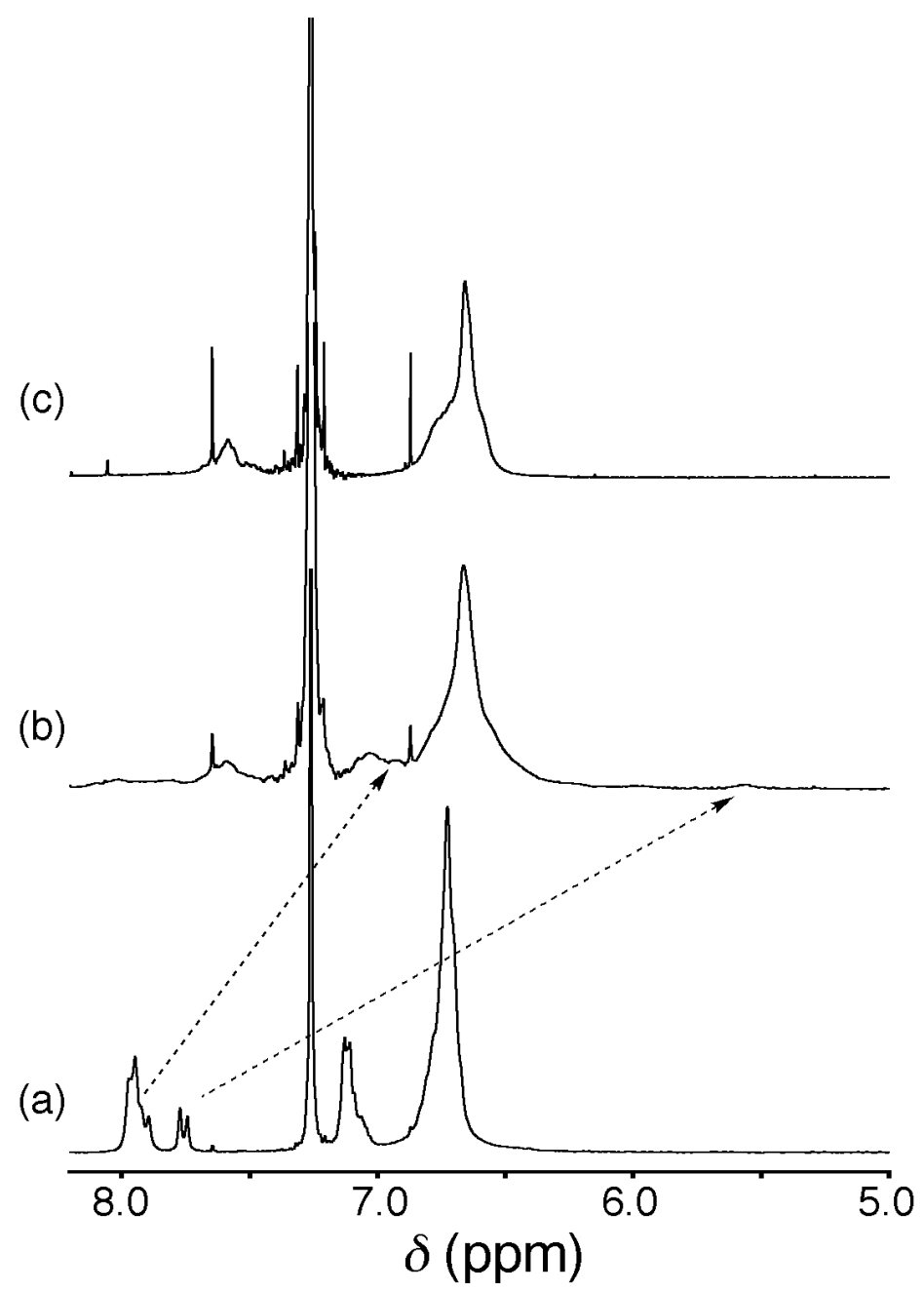

Fig. 5. ${ }^{1} \mathrm{H}$ NMR spectral change of $\left[\mathrm{H}_{4} \mathrm{DPP}\left(\mathrm{CO}_{2} \mathrm{H}\right)\right]\left(\mathrm{ClO}_{4}\right)_{2}$ upon addition of $(\mathrm{Me})_{4} \mathrm{NOH}$ in $\mathrm{CDCl}_{3}$. (a) $\left[\mathrm{H}_{4} \mathrm{DPP}\left(\mathrm{CO}_{2} \mathrm{H}\right)\right]\left(\mathrm{ClO}_{4}\right)_{2}$ (b) $\left[\mathrm{H}_{4} \mathrm{DPP}\left(\mathrm{CO}_{2} \mathrm{H}\right)\right]\left(\mathrm{ClO}_{4}\right)_{2}+1$ eq of $(\mathrm{Me})_{4} \mathrm{NOH}$ (c) $\left[\mathrm{H}_{4} \mathrm{DPP}\left(\mathrm{CO}_{2} \mathrm{H}\right)\right]$ $\left(\mathrm{ClO}_{4}\right)_{2}+3$ eq of $(\mathrm{Me})_{4} \mathrm{NOH}$.

$\mathrm{CDCl}_{3}$ (Fig. 5). In the initial spectrum, a doublet due to the $m-\mathrm{H}$ of the meso-carboxyphenyl group was observed at $7.76 \mathrm{ppm}(J=8 \mathrm{~Hz})$ and multiplets appeared at 7.85-8.0 and 6.55-7.00 ppm were assigned to the $o-\mathrm{H}$ of meso-carboxyphenyl and meso-phenyl groups and the $\beta$-phenyl groups, respectively (Fig. 5(a)). Addition of 1 eq of $\mathrm{Me}_{4} \mathrm{NOH}$ made the spectrum broadened (Fig. 5(b)) and further addition of 2 more eq of $\mathrm{Me}_{4} \mathrm{NOH}$ gave the upfield-shifted and sharp signals at 7.50-7.74, 7.15-7.40 and 6.43-6.98 ppm for the meso-carboxyphenyl, meso-phenyl and the $\beta$-phenyl groups, respectively (Fig. 5(c)). Based on the UV-Vis titration experiment, the spectra obtained by the addition of 1 eq of $\mathrm{Me}_{4} \mathrm{NOH}$ was assigned to that of $\left[\mathrm{H}_{4} \mathrm{DPP}(\mathrm{COO})\right]^{+}$and significant up-field shifts of ${ }^{1} \mathrm{H}$ NMR signals were observed for the carboxylate-phenyl protons. The chemical shifts were 6.94 and $5.56 \mathrm{ppm}$ for $o$ - and $m$-phenyl protons, which were originally observed at 7.97 and 7.76 ppm, respectively (see the dotted arrows in Fig. 5). This up-field shifts were probably due that they 
were positioned above the porphyrin ring of other molecules and were affected by the shielding effect of the ring current [28].

As described above, 1 eq addition of $\mathrm{Me}_{4} \mathrm{NOH}$ to the solution of $\left[\mathrm{H}_{4} \mathrm{DPP}\left(\mathrm{CO}_{2} \mathrm{H}\right)\right]^{2+}$ afforded the carboxylate-appended porphyrin dication and the formation of supramolecular structures was assumed on the basis of the results of the UV-Vis and ${ }^{1} \mathrm{H}$ NMR spectroscopic measurements. At this point, although we have not obtained any definitive evidence to support yet, we assume the supramolecular structure formed by the self-assembly of $\left[\mathrm{H}_{4} \mathrm{DPP}(\mathrm{COO})\right]^{+}$as depicted in Scheme 3 , based on our previous observations on formation of hydrogen-bonded supramolecular assemblies made of $\mathrm{H}_{4} \mathrm{DPP}^{2+}$ and carboxylate-appended molecular components $[11,12,14,26]$.

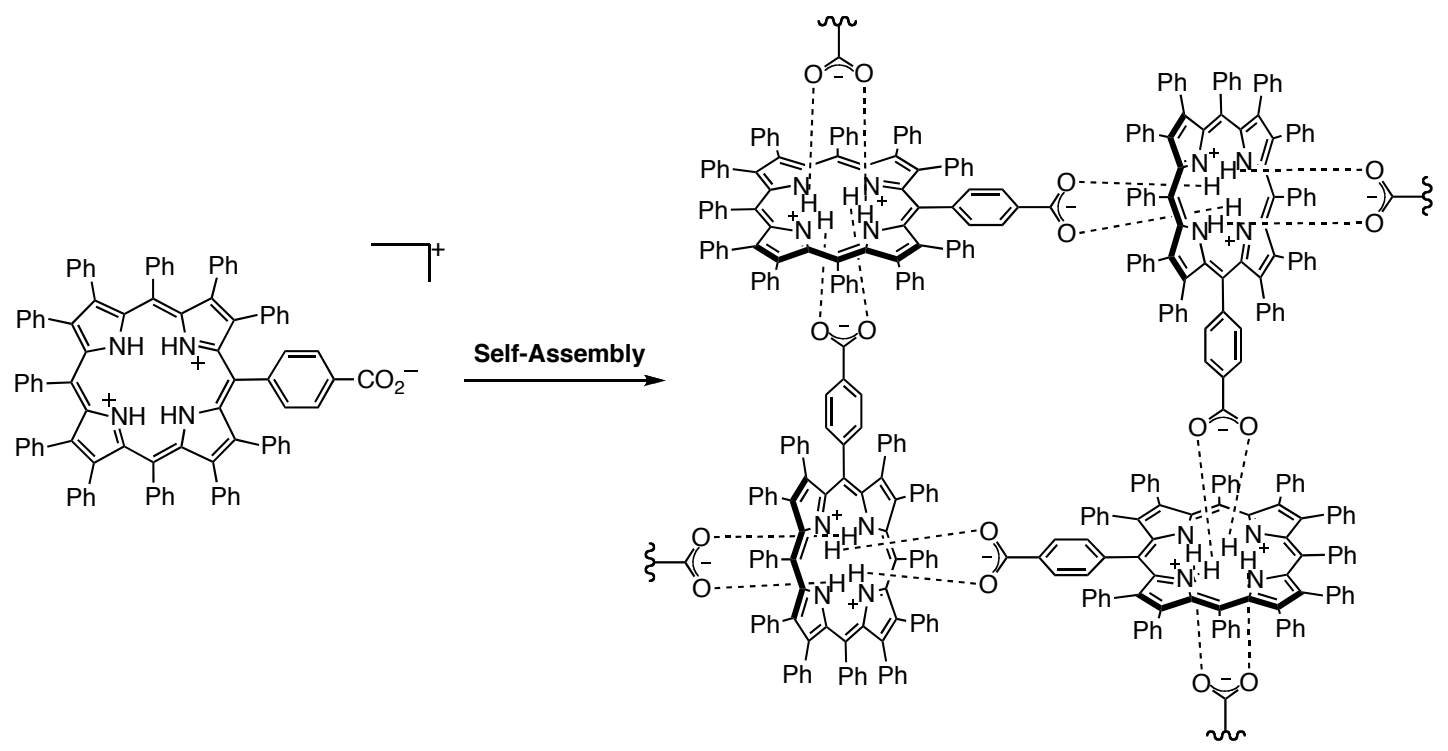

Scheme 3. A Possible Self-Assembled Structure of $\left[\mathrm{H}_{4} \mathrm{DPP}(\mathrm{COO})\right]^{+}$.

Cell Fabrication and Photovoltaic Characteristics: The porphyrins were adsorbed as photosensitizers onto $\mathrm{TiO}_{2}$ and $\mathrm{SnO}_{2}$ nanocrystalline films to serve as working electrodes in dyesensitized Solar cells (DSSCs) [29]. The working electrodes were prepared as mentioned in the experimental section and then they were immersed into a solution of porphyrin $\left(\left(\mathrm{HNEt}_{3}\right)\left[\mathrm{H}_{2} \mathrm{DPP}(\mathrm{COO})\right]\right.$ or $\left.\mathrm{ZnDPP}\left(\mathrm{CO}_{2} \mathrm{H}\right)\right)$ in $\mathrm{CH}_{2} \mathrm{Cl}_{2} / \mathrm{EtOH}(9: 1 \mathrm{v} / \mathrm{v})$. Pt electrodes were used as counter electrodes. The DSSCs were fabricated by sandwiching a redox $\left(\mathrm{I}^{-} / \mathrm{I}_{3}{ }^{-}\right)$electrolyte solution. Through measurements of $I-V$ curves, we assessed the performance of the DSSC devices and the open-circuit photovoltage $\left(V_{\mathrm{oc}}\right)$, the short-circuit photocurrent density $\left(J_{\mathrm{SC}}\right)$, fill factor $(F F)$ and power conversion efficiency (PCE, $\eta$ ) were summarized in Table 2 . The $I-V$ curves of the solar cells made of the porphyrin/ $\mathrm{TiO}_{2}$ sensitized films are shown in Fig. S1 in the supporting information. The $\operatorname{PCE}(\eta)$ value for $\left(\mathrm{HNEt}_{3}\right)\left[\mathrm{H}_{2} \mathrm{DPP}(\mathrm{COO})\right]$ is similar to that for $\mathrm{ZnDPP}\left(\mathrm{CO}_{2} \mathrm{H}\right)$ (entry $1 \& 3$ ). When chenodeoxycholic acid (CDCA) was added as a co-adsorbate for dye-loading to avoid aggregation 
of the dye on the $\mathrm{TiO}_{2}$ surface (entry $2 \& 4$ ) [29b], the improvement of $J_{\mathrm{SC}}$ and $V_{\mathrm{OC}}$ was not observed both for the cases of $\left(\mathrm{HNEt}_{3}\right)\left[\mathrm{H}_{2} \mathrm{DPP}(\mathrm{COO})\right]$ and $\mathrm{ZnDPP}\left(\mathrm{CO}_{2} \mathrm{H}\right)$. This means that the aggregation of the porphyrins on the $\mathrm{TiO}_{2}$ and $\mathrm{SnO}_{2}$ surface seems not severe. We also fabricated DSSCs based on $\mathrm{SnO}_{2}$ film electrodes adsorbed the porphyrin sensitizers. Although the conduction band of $\mathrm{SnO}_{2}$ is lower than that of $\mathrm{TiO}_{2}$ to show further enhancement in the efficiency, the results were not much improved. Regarding the reasons for the low efficiency for both of the DSSCs based on the $\mathrm{TiO}_{2}$ and $\mathrm{SnO}_{2}$ working electrodes, one is desorption of porphyrins from the electrode surfaces during the measurements and another would be the proximity of the oxidation potentials

(a)

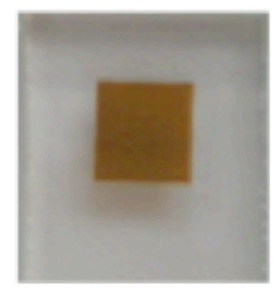

(b)

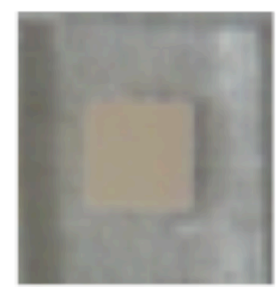

(c)

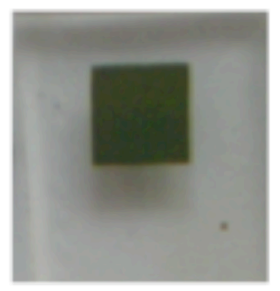

(d)

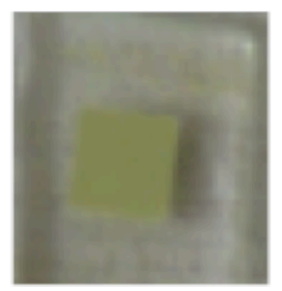

Fig. 6. Images of dye-sensitized films (a) of $\left(\mathrm{HNEt}_{3}\right)\left[\mathrm{H}_{2} \mathrm{DPP}(\mathrm{COO})\right]$ on $\mathrm{TiO}_{2}$ and (b) on $\mathrm{SnO}_{2}$ films and (c) of $\mathrm{ZnDPP}\left(\mathrm{CO}_{2} \mathrm{H}\right)$ on $\mathrm{TiO}_{2}$ and (d) on $\mathrm{SnO}_{2}$ films.

Table 2. Photovoltaic Parameters of MCDPP-Sensitized Solar Cells.

\begin{tabular}{|c|c|c|c|c|c|}
\hline entry & sensitizer & $\begin{array}{c}V_{\text {oc }} \\
{[\mathrm{mV}]}\end{array}$ & $\begin{array}{c}J_{\mathrm{SC}} \\
{\left[\mathrm{mA} \mathrm{cm}^{-2}\right]}\end{array}$ & $\begin{array}{c}\eta \\
{[\%]}\end{array}$ & $F F$ \\
\hline $1^{\mathrm{a}}$ & $\left(\mathrm{HNEt}_{3}\right)\left[\mathrm{H}_{2} \mathrm{DPP}(\mathrm{COO})\right]$ & 430 & 0.21 & 0.07 & 0.76 \\
\hline $2^{\mathrm{a}}$ & $\begin{array}{c}\left(\mathrm{HNEt}_{3}\right)\left[\mathrm{H}_{2} \mathrm{DPP}(\mathrm{COO})\right] \\
+\mathrm{CDCA}\end{array}$ & 390 & 0.19 & 0.15 & 0.67 \\
\hline $3^{\mathrm{a}}$ & $\mathrm{ZnDPP}\left(\mathrm{CO}_{2} \mathrm{H}\right)$ & 530 & 0.25 & 0.10 & 0.67 \\
\hline $4^{\mathrm{a}}$ & $\mathrm{ZnDPP}\left(\mathrm{CO}_{2} \mathrm{H}\right)+$ & 560 & 0.11 & 0.14 & 0.70 \\
\hline $5^{\mathrm{C}}$ & $\left(\mathrm{HNEt}_{3}\right)\left[\mathrm{H}_{2} \mathrm{DPP}(\mathrm{COO})\right]$ & 300 & 0.13 & 0.03 & 0.72 \\
\hline $6^{\mathrm{b}}$ & ${\mathrm{ZnDPP}\left(\mathrm{CO}_{2} \mathrm{H}\right)}^{\mathrm{Cn}}$ & 390 & 0.52 & 0.13 & 0.62 \\
\hline
\end{tabular}

${ }^{\mathrm{a}}$ Use of $\mathrm{TiO}_{2}$ electrode. ${ }^{\mathrm{b}}$ Use of $\mathrm{SnO}_{2}$ electrode. 
between $\mathrm{DPP}\left(\mathrm{CO}_{2} \mathrm{H}\right) \mathrm{s}$ and $\mathrm{I}^{-}$to give less efficiency of the dye regeneration by the reduction of radical cations of $\mathrm{DPP}\left(\mathrm{CO}_{2} \mathrm{H}\right) \mathrm{s}$.

\section{CONCLUSION}

Supramolecular structures of a saddle-distorted porphyrin with a carboxyl group as a hydrogen-bonding site were confirmed by the X-ray diffraction analysis. $\left[\mathrm{H}_{4} \mathrm{DPP}\left(\mathrm{CO}_{2} \mathrm{H}\right)\right]^{2+}$, having a carboxyphenyl group at a meso position, formed a nanochannel structure by self-assembly and the nanochannel structure was similar to that consisted of $\mathrm{H}_{4} \mathrm{DPP}^{2+}$. In the nanochannel structure of $\left[\mathrm{H}_{4} \mathrm{DPP}\left(\mathrm{CO}_{2} \mathrm{H}\right)\right]^{2+}$, however, intermolecular complementary hydrogen bonding of the carboxyl groups was formed to regulate the mutual distances between the nanochannels. As well as the inner space of the nanochannel [9], the resulting interchannel spaces can be also used to include functional guest molecules. The deprotonation of the carboxyl group in $\left[\mathrm{H}_{4} \mathrm{DPP}\left(\mathrm{CO}_{2} \mathrm{H}\right)\right]^{2+}$ afforded another supramolecular structures derived from its self-assembly in solution by virtue of intermolecular hydrogen bonding between the appended carboxylate group and the diprotonated porphyrin core as observed in the combination of $\mathrm{H}_{4} \mathrm{DPP}^{2+}$ with molecules having a carboxylate group $[11,12,26]$. We have also examined the DSSC performances of $\left(\mathrm{HNEt}_{3}\right)\left[\mathrm{H}_{2} \mathrm{DPP}(\mathrm{COO})\right]^{-}$and $\mathrm{ZnDPP}\left(\mathrm{CO}_{2} \mathrm{H}\right)$ and the efficiencies were moderate but the further investigation for the improvement of the efficiency by avoiding desorption and the alteration of sacrificial reductants to sufficiently regenerate sensitizing dyes is currently underway.

\section{REFERENCES}

1. (a) Wasielewski MR, Chem.Rev. 1992; 92: 435-461. (b) Medforth CJ, Wang Z, Martin KE, Song Y, Jacobsen JL, Shelnutt JA, Chem. Commun. 2009; 7261-7277. (c) Wasielewski MR, Acc. Chem. Res. 2009; 42: 1910-1921.

2. (a) Martinez-Diaz MM, Torre GDL, Torres T, Chem. Commun. 2010; 46: 7090-7108. (b) Odobel F, Pleux LL, Pellegrin Y, Blart E, Acc. Chem. Res. 2010; 43: 1063-1071. (c) Gust D, Moore TA, Moore AL, Acc. Chem. Res. 2009; 42: 1890-1898. (d) Drain CM, Varotto A, Radivojevic I, Chem. Rev. 2009; 109: 1630-1658.

3. (a) Kim D, Heo J, Ham S, Yoo H, Lee CH, Yoon H, Ryu D, Kim D, Jang WD, Chem. Commun. 2011; 47: 2405-2407. (b) Tsuda A, Nagamine Y, Watanabe R, Nagatani Y, Ishii N, Aida T, Nat. Chem. 2010; 2: 977-983. (c) Ohkawa H, Takayama A, Nakajima S, Nishide H, Org. Lett. 2006; 8: 2225-2228. (d) Goldberg I, Chem. Commun. 2005; 1243-1254. (e) Yamaguchi T, 
Ishii N, Tashiro K, Aida T, J. Am. Chem. Soc. 2003; 125: 13934-13935. (f) Bhyrappa P, Wilson SR, Suslick KS, J. Am. Chem. Soc. 1997; 119: 8492-8502.

4. (a) Nobukuni H, Shimazaki Y, Tani F, Naruta Y, Angew. Chem., Int. Ed. 2007; 46: 8975-8978.

(b) Gao Y, Zhang X, Ma C, Li X, Jiang J, J. Am. Chem. Soc. 2008; 130: 17044-17052. (c) Hunter CA, Sanders JKM, J. Am. Chem. Soc. 1990; 112: 5525-5534.

5. Muniappan S, Lipstman S, Goldberg I, Chem. Commun. 2008; 1777-1779.

6. (a) Liu T, Schneider HJ, Angew. Chem., Int. Ed. 2002; 46: 1368-1370. (b) Kano K, Fukuda K, Wakami H, Nishiyabu R, Pasternack RF, J. Am. Chem. Soc. 2000; 122: 7494-7502.

7. (a) Medforth CJ, Senge MO, Smith KM, Sparks LD, Shelnutt JA, J. Am. Chem. Soc. 1992; 114: 9859-9869. (b) Gentemann S, Medforth CJ, Forsyth TP, Nurco DJ, Smith, KM, Fajer, J, Holten, D, J. Am. Chem. Soc. 1994; 116: 7363-7368. (c) Nurco DJ, Medforth CJ, Forsyth TP, Olmstead MM, Smith KM, J. Am. Chem. Soc. 1996; 118: 10918-10919. (d) Retsek JL, Medforth CJ, Nurco DJ, Gentemann S, Chirvony VS, Smith KM, Holten D, J. Phys. Chem. B 2001; 105: 6396-6411. (e) Retsek JL, Drain CM, Kirmaier C, Nurco DJ, Medforth CJ, Smith KM, Sazanovich IV, Chirvony VS, Fajer J, Holten D, J. Am. Chem. Soc. 2003; 125: 9787-9800.

8. (a) Harada R, Matsuda Y, Okawa H, Kojima T, Angew. Chem., Int. Ed. 2004; 43: 1825-1828. (b) Kojima T, Harada R, Nakanishi T, Kaneko K, Fukuzumi S, Chem. Mater. 2007; 19: 51-58. (c) Yokoyama, A, Kojima T, Fukuzumi S, Dalton Trans. 2011: in press (DOI:10.1039/ C0DT01708F).

9. (a) Nakanishi T, Kojima T, Ohkubo K, Hasobe T, Nakayama K, Fukuzumi S, Chem. Mater. 2008; 21: 7492-7500. (b) Kojima T, Nakanishi T, Harada R, Ohkubo K, Yamauchi S, Fukuzumi S, Chem. Eur. J. 2007; 13: 8714-8725. (c) Harada R, Kojima T, Chem. Commun. 2005; 716-718. 10. Nakanishi T, Ohkubo K, Kojima T, Fukuzumi S, J. Am. Chem. Soc. 2009; 131: 577-584.

11. Kojima T, Honda T, Ohkubo K, Shiro M, Kusukawa T, Fukuda T, Kobayashi N, Fukuzumi S, Angew. Chem., Int. Ed. 2008; 47: 6712-6716.

12. Honda T, Nakanishi T, Ohkubo K, Kojima T, Fukuzumi S, J. Am. Chem. Soc. 2010; 132: 10155-10163.

13. Balaz M, Holmes AE, Benedetti M, Proni G, Berova N, Bio. Med. Chem. 2005; 13: 2413-2421.

14. Honda T, Nakanishi T, Ohkubo K, Kojima T, Fukuzumi, S, J. Phys. Chem. C 2010; 114: 1429014299.

15. Bhyrappa P, Krishnan V, Inorg. Chem. 1991; 30: 239-245.

16. CrystalStructure, Crystal Structure Analysis Package, 3.7.0; Rigaku and Rigaku/MSC: The Woodlands, TX, 2000-2005. 
17. Wakita, K. Yadokari-XG, Software for Crystal Structure Analyses, 2001. Kabuto, C.; Akine, S.; Nemoto, T.; Kwon, E. Release of Software (Yadokari-XG 2009) for Crystal Structure Analyses. J. Cryst. Soc. Jpn. 2009, 51, 218.

18. Sheldrick GM, SIR 97 and SHELX 97, Program for Crystal Structures Refinement; University of Göttingen: Göttingen, Germany, 1997.

19. Sluis PVD, Spek AL, Acta Crystallogr. 1990; A46: 194-201.

20. Ma T, Kida T, Akimiya M, Inoue K, Tsunematsu S, Yao K, Abe E, Electrochem. Commun. 2003; 5: 369-372.

21. Medforth CJ, Smith KM, Tetrahedron Lett. 1990; 31: 5583-5586.

22. The UV-Vis spectrum of the crystalline sample in THF also supported the assignment that the $\left(\mathrm{HNEt}_{3}\right)\left[\mathrm{H}_{2} \mathrm{DPP}(\mathrm{COO})\right]$ was protonated during the recrystallization. The spectra exhbited intense absorption around $715 \mathrm{~nm}$ and the Soret band (492) showed red shift by $24 \mathrm{~nm}$ compared to that of $\left[\mathrm{H}_{2} \mathrm{DPP}(\mathrm{COO})\right]^{-}$formed by adding excess amount of triethylamine and the spectroscopic observations corresponded to the specific features of diprotonated DPPs.

23. One of the oxygen atoms of the carboxyl group without forming hydrogen bond in Fig. 2(b) was found to form hydrogen bonding with a severely disordered $i$-PrOH molecule of crystallization, which was eliminated by the Squeeze method.

24. Absorption maxima of the Soret band in $\mathrm{CH}_{2} \mathrm{Cl}_{2}: 468 \mathrm{~nm}$ for $\mathrm{H}_{2} \mathrm{DPP}, 491 \mathrm{~nm}$ for $\mathrm{H}_{4} \mathrm{DPPCl}_{2}$, and $465 \mathrm{~nm}$ ZnDPP.

25. Emission maxima in $\mathrm{CH}_{2} \mathrm{Cl}_{2}: 786 \mathrm{~nm}$ for $\mathrm{H}_{2} \mathrm{DPP}, 761 \mathrm{~nm}$ for $\mathrm{H}_{4} \mathrm{DPPCl}_{2}$, and $684 \mathrm{~nm} \mathrm{ZnDPP}$.

26. Honda T, Kojima T, Fukuzumi S, Chem. Commun. 2009; 4994-4996.

27. Kano K, Fukuda K, Wakami H, Nishiyabu R, Pasternack RF, J. Am. Chem. Soc. 2000; 122: 7494-7502.

28. In the previous report (see ref. 11), we observed the ${ }^{1} \mathrm{H}$ signals for 4-pyridine carboxylate in the $\left(\mathrm{H}_{4} \mathrm{DPP}\right)(4-\text { pyridine carboxylate })_{2}$ supramolecule at 5.97 and $7.68 \mathrm{ppm}$ for the 3,5- and 2,6protons, respectively. The degree of the up-field shifts is similar to those observed in this work.

29. (a) Bessho T, Zakeeruddin SM, Yeh CY, Diau EWG, Grätzel M, Angew. Chem., Int. Ed. 2010; 49: 6646-6649. (b) Lee, CW, Lu HP, Lan, CM, Huang, YL, Liang YR, Yen WN, Liu YC, Lin YS, Diau EWG, Yeh CY, Chem. Eur. J. 2009; 15: 1403-1412.

\section{Acknowledgements.}

This work was supported by Grants-in-Aid for Scientific Research (Nos. 21350035 and 20108010) from JSPS and MEXT. M. S. appreciate a support from a JSPS postdoctoral fellowship (No. 09049). This work was also supported by the National High Technology Research and 
Development Program for Advanced Materials of China (Grant 2009AA03Z220). We appreciate Prof. Tatsuya Nabeshima (University of Tsukuba) for his kind accommodation for the fluorescence measurements.

\section{Supporting information.}

$I-V$ curves for the DSSCs using $\left(\mathrm{HNEt}_{3}\right)\left[\mathrm{H}_{2} \mathrm{DPP}(\mathrm{COO})\right]$ and $\mathrm{ZnDPP}\left(\mathrm{CO}_{2} \mathrm{H}\right)$ and the crystallographic data for $\left[\mathrm{H}_{4} \mathrm{DPP}\left(\mathrm{CO}_{2} \mathrm{H}\right)\right](\mathrm{OH})_{2}$ in the cif format. This material is available at http://www.u-bourgogne.fr/jpp/. 


\section{Graphical Abstract}

\section{Synthesis, Structure and Physicochemical Properties of a Saddle-Distorted Porphyrin with}

a Peripheral Carboxyl Group

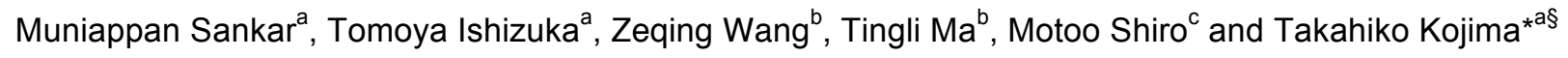

A saddle-distorted porphyrin bearing a carboxyl group as a hydrogen-bonding site at the peripheral position was synthesized and structurally characterized by X-ray crystallography. The porphyrin formed a nanochannel structure based on the curvature of the porphyrin core and the relative spatial arrangement between the channels was regulated by the formation of interchannel hydrogen bonds. We also report its self-assembly in solution and its application to a dye-sensitized solar cell.

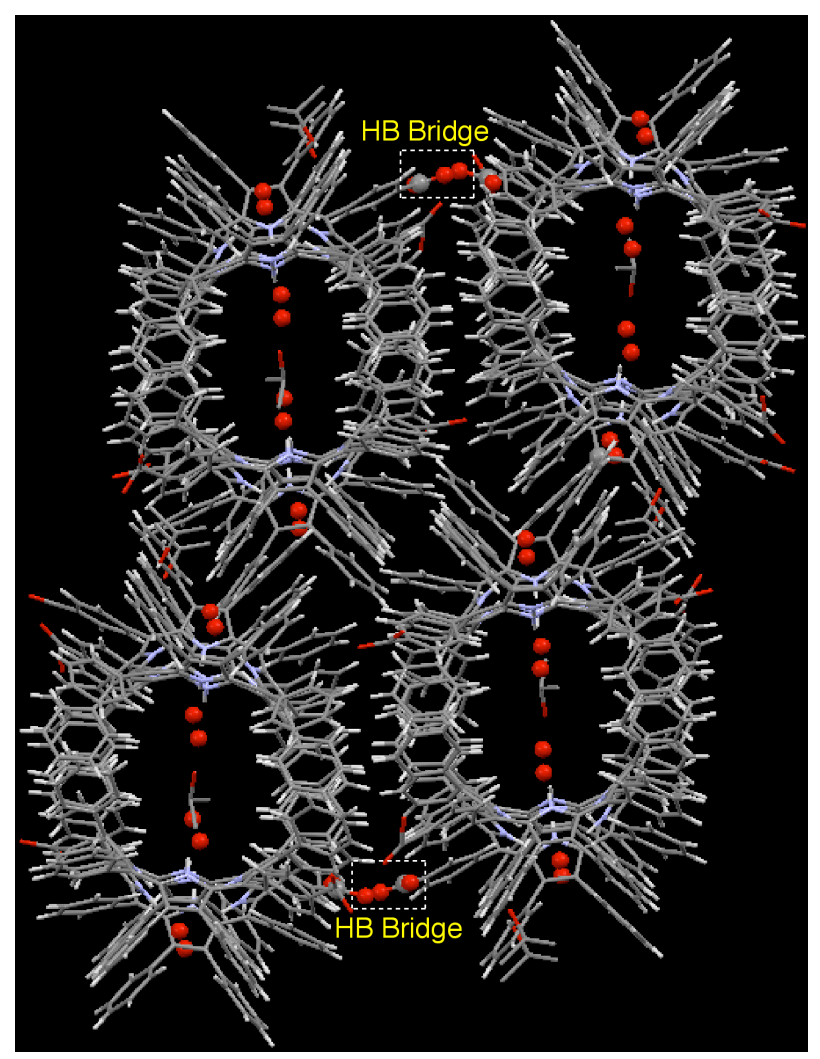

